\title{
‡USGS
}

science for a changing world

In cooperation with

NEW YORK STATE DEPARTMENT OF ENVIRONMENTAL CONSERVATION

\section{Ground-Water Quality in the Mohawk River Basin, New York, 2006}

By Elizabeth A. Nystrom

Open-File Report 2008-1086

U.S. Department of the Interiot U.S. Geological Survey 
Cover.-Photograph by Elizabeth Nystrom, U.S. Geological Survey. 


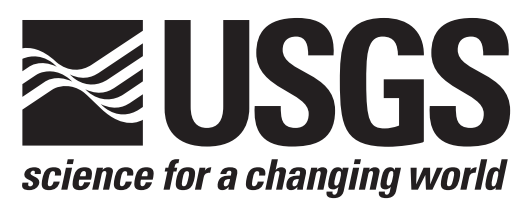

In cooperation with

NEW YORK STATE DEPARTMENT OF ENVIRONMENTAL CONSERVATION

\section{Ground-Water Quality in the Mohawk River Basin, New York, 2006}

By Elizabeth A. Nystrom

Open-File Report 2008-1086

U.S. Department of the Interior

U.S. Geological Survey 


\title{
U.S. Department of the Interior \\ DIRK KEMPTHORNE, Secretary
}

\author{
U.S. Geological Survey \\ Mark D. Myers, Director
}

U.S. Geological Survey, Reston, Virginia 2008

For more information on the USGS - the Federal source for science about the Earth, its natural and living resources, natural hazards, and the environment: World Wide Web: http://www.usgs.gov

Telephone: 1-888-ASK-USGS

Suggested citation:

Nystrom, E.A., 2008, Ground-water quality in the Mohawk River Basin, New York, 2006: U.S. Geological Survey Open-File Report 2008-1086, 33 p., online only.

Any use of trade, product, or firm names is for descriptive purposes only and does not imply endorsement by the U.S. Government. 


\section{Contents}

Abstract

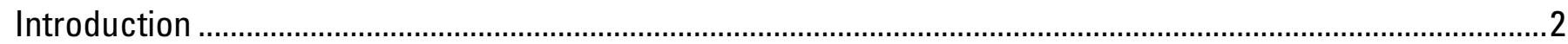

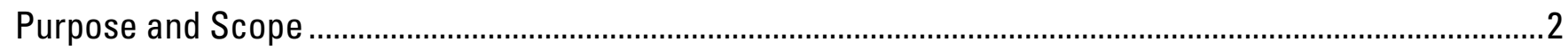

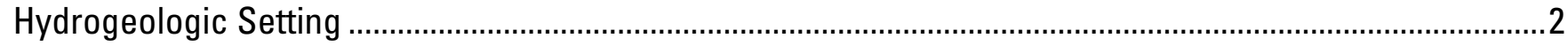

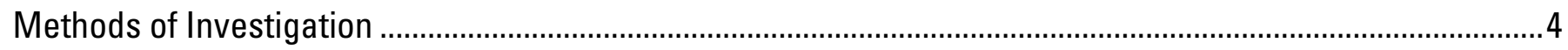

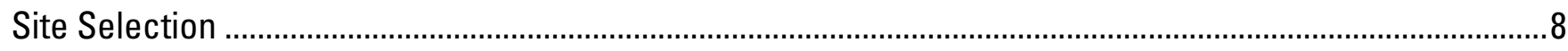

Sampling Methods

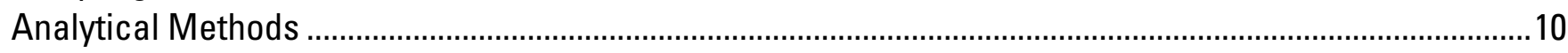

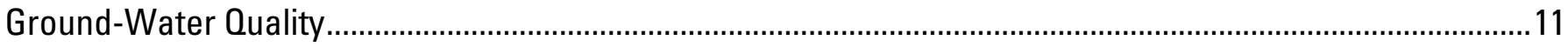

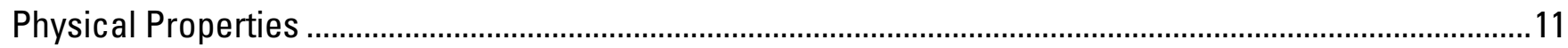

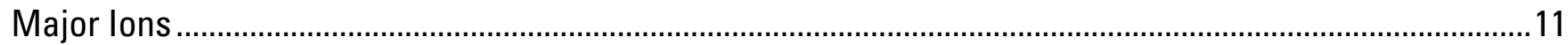

Nutrients and Organic Carbon ...................................................................................................... 13

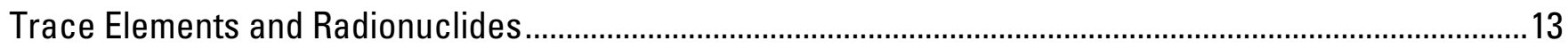

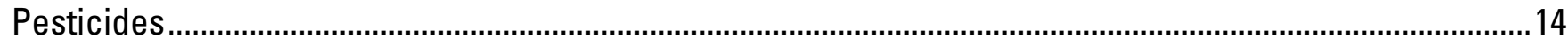

Volatile Organic Compounds and Phenolic Compounds ..........................................................................

Bacteria

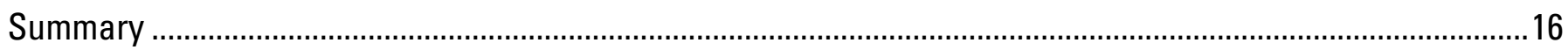

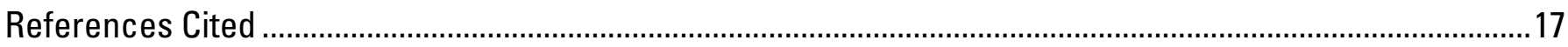

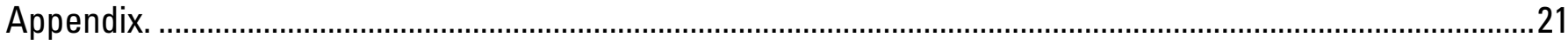

\section{Figures}

Figure 1. Hydrologic and geographic features and location of the Mohawk River Basin in central New York.

Figure 2. Topography, physiographic regions, and locations of wells sampled in the Mohawk River Basin...5

Figure 3. Land cover and locations of wells sampled in the Mohawk River Basin............................................

Figure 4. Generalized bedrock geology and locations of wells sampled in the Mohawk River Basin..............7

\section{Tables}

Table 1. Drinking water standards and summary statistics for concentrations of major ions in ground-water samples from the Mohawk River Basin, 2006.

Table 2. Drinking water standards and summary statistics for concentrations of nutrients in ground-water samples from the Mohawk River Basin, 2006.

Table 3. Drinking water standards and summary statistics for concentrations of trace elements and radon-

222 in ground-water samples from the Mohawk River Basin, 2006.

Table A1. Information on wells sampled in the Mohawk River Basin, 2006...................................................21

Table A2. Constituents analyzed for but not detected in ground-water samples from the Mohawk River

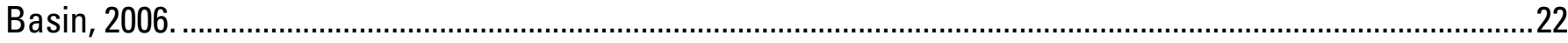

Table A3. Physical properties of ground-water samples from the Mohawk River Basin, 2006.......................24

Table A4. Concentrations of major ions in ground-water samples from the Mohawk River Basin, 2006.......25 
Table A5. Concentrations of nutrients and organic carbon in ground-water samples from the Mohawk River

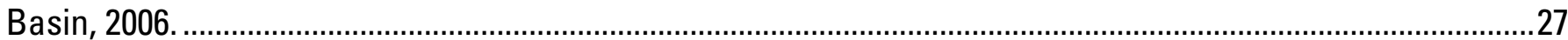

Table A6. Concentrations of trace elements and radionuclides in ground-water samples from the Mohawk

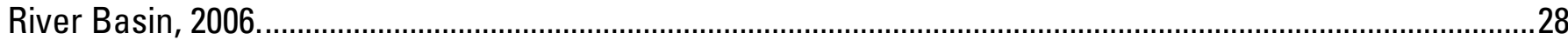

Table A7. Concentrations of pesticides and caffeine detected in ground-water samples from the Mohawk River Basin, 2006. ...31

Table A8. Concentrations of volatile organic compounds and phenolic compounds detected in groundwater samples from the Mohawk River Basin, 2006.

Table A9. Bacteria in ground-water samples from the Mohawk River Basin, 2006. 33 


\section{Conversion Factors, Datum, Abbreviated Water-Quality Units, and Acronyms}

\begin{tabular}{lcl}
\hline \multicolumn{1}{c}{ Multiply } & By & \multicolumn{1}{c}{ To obtain } \\
\hline centimeter $(\mathrm{cm})$ & Length & \\
foot $(\mathrm{ft})$ & 0.3937 & inch $(\mathrm{in})$. \\
& 0.3048 & meter $(\mathrm{m})$ \\
\hline acre & Area & \\
\hline square mile $\left(\mathrm{mi}^{2}\right)$ & 0.004047 & square kilometer $\left(\mathrm{km}^{2}\right)$ \\
\hline & 2.590 & square kilometer $\left(\mathrm{km}^{2}\right)$ \\
\hline liter $(\mathrm{L})$ & Volume & \\
gallon $(\mathrm{gal})$ & 0.2642 & gallon $($ gal) \\
\hline & 3.785 & liter $(\mathrm{L})$ \\
\hline gallon per minute $(\mathrm{gal} / \mathrm{min})$ & Flow rate & \\
\hline inch per year (in/yr) & 0.06309 & liter per second $(\mathrm{L} / \mathrm{s})$ \\
\hline & 25.4 & millimeter per year $(\mathrm{mm} / \mathrm{yr})$ \\
\hline picocurie per liter (pCi/L) & Radioactivity & \\
\hline
\end{tabular}

Temperature in degrees Celsius $\left({ }^{\circ} \mathrm{C}\right)$ may be converted to degrees Fahrenheit $\left({ }^{\circ} \mathrm{F}\right)$ as follows:

${ }^{\circ} \mathrm{F}=\left(1.8 \mathrm{x}^{\circ} \mathrm{C}\right)+32$

Vertical coordinate information is referenced to the North American Vertical Datum of 1988 (NAVD 88).

Horizontal coordinate information is referenced to the North American Datum of 1983 (NAD 83).

Altitude, as used in this report, refers to distance above the vertical datum.

Abbreviated water-quality units used in this report:

micrograms per liter $(\mu \mathrm{g} / \mathrm{L})$

milligrams per liter $(\mathrm{mg} / \mathrm{L})$

microsiemens per centimeter at 25 degrees Celsius $\left(\mu \mathrm{S} / \mathrm{cm}\right.$ at $\left.25^{\circ} \mathrm{C}\right)$

platinum-cobalt units (Pt-Co units) 
Acronyms used in this report

$\begin{array}{ll}\text { AMCL } & \text { Alternative maximum contaminant level } \\ \text { CFU } & \text { Colony-forming units } \\ \text { cICP-MS } & \text { Collision/reaction cell inductively coupled plasma-mass spectrometry } \\ \text { ESA } & \text { Ethanesulfonic acid } \\ \text { GC-MS } & \text { Gas chromatography-mass spectrometry } \\ \text { GPS } & \text { Global positioning system } \\ \text { GWSI } & \text { Ground-Water Site-Inventory } \\ \text { HPLC-MS } & \text { High-performance liquid chromatography-mass spectrometry } \\ \text { ICP-AES } & \text { Inductively coupled plasma-atomic emission spectrometry } \\ \text { ICP-MS } & \text { Inductively coupled plasma-mass spectrometry } \\ \text { ICP-OES } & \text { Inductively coupled plasma-optical emission spectrometry } \\ \text { LC-MS } & \text { Liquid chromatography-mass spectrometry } \\ \text { MCL } & \text { Maximum contaminant level } \\ \text { MTBE } & \text { Methyl tert-butyl ether } \\ \text { NWQL } & \text { USGS National Water Quality Laboratory } \\ \text { NYSDEC } & \text { New York State Department of Environmental Conservation } \\ \text { NYSDOH } & \text { New York State Department of Health } \\ \text { OGRL } & \text { USGS Organic Geochemistry Research Laboratory } \\ \text { PERC } & \text { Tetrachloroethene } \\ \text { POC } & \text { Principal organic contaminant } \\ \text { PVC } & \text { Polyvinyl chloride } \\ \text { SDWS } & \text { Secondary drinking water standards } \\ \text { THM } & \text { Trihalomethane } \\ \text { TTHMs } & \text { Total trihalomethanes } \\ \text { USEPA } & \text { U.S. Environmental Protection Agency } \\ \text { USGS } & \text { U.S. Geological Survey } \\ \text { VOC } & \text { Volatile organic compound } \\ & \end{array}$




\title{
Ground-Water Quality in the Mohawk River Basin, New York, 2006
}

\author{
By Elizabeth A. Nystrom
}

\section{Abstract}

Water samples were collected from 27 wells from August through November 2006 to characterize ground-water quality in the Mohawk River Basin. The Mohawk River Basin covers 3,500 square miles in central New York; most of the basin is underlain by sedimentary bedrock, including shale, sandstone, and carbonates. Sand and gravel form the most productive aquifers in the basin. Samples were collected from 13 sand and gravel wells and 14 bedrock wells, including production and domestic wells. The samples were collected and processed through standard U.S. Geological Survey procedures and were analyzed for 226 physical properties and constituents, including physical properties, major ions, nutrients, trace elements, radon-222, pesticides, volatile organic compounds, and bacteria.

Many constituents were not detected in any sample, but concentrations of some constituents exceeded current or proposed Federal or New York State drinking-water quality standards, including color (1 sample), pH (2 samples), sodium (11 samples), chloride (2 samples), fluoride (1 sample), sulfate (1 sample), aluminum (2 samples), arsenic (2 samples), iron (10 samples), manganese (10 samples), radon-222 (12 samples), and bacteria (6 samples). Dissolved oxygen concentrations were greater in samples from sand and gravel wells (median 5.6 milligrams per liter $[\mathrm{mg} / \mathrm{L}]$ ) than from bedrock wells (median $0.2 \mathrm{mg} / \mathrm{L}$ ). The $\mathrm{pH}$ was typically neutral or slightly basic (median 7.3 ); the median water temperature was $11^{\circ} \mathrm{C}$. The ions with the highest concentrations were bicarbonate (median $276 \mathrm{mg} / \mathrm{L}$ ), calcium (median $58.9 \mathrm{mg} / \mathrm{L}$ ), and sodium (median $41.9 \mathrm{mg} / \mathrm{L}$ ). Ground water in the basin is generally very hard $\left(180 \mathrm{mg} / \mathrm{L}\right.$ as $\mathrm{CaCO}_{3}$ or greater), especially in the Mohawk Valley and areas with carbonate bedrock. Nitrate-plus-nitrite concentrations were generally higher samples from sand and gravel wells (median concentration $0.28 \mathrm{mg} / \mathrm{L}$ as $\mathrm{N}$ ) than in samples from bedrock wells (median $<0.06 \mathrm{mg} / \mathrm{L}$ as $\mathrm{N}$ ), although no concentrations exceeded established State or Federal drinkingwater standards of $10 \mathrm{mg} / \mathrm{L}$ as $\mathrm{N}$ for nitrate and $1 \mathrm{mg} / \mathrm{L}$ as $\mathrm{N}$ for nitrite. Ammonia concentrations were higher in samples from bedrock wells (median $0.349 \mathrm{mg} / \mathrm{L}$ as $\mathrm{N}$ ) than in those from samples from sand and gravel wells (median $0.006 \mathrm{mg} / \mathrm{L}$ as $\mathrm{N}$ ). The trace elements with the highest concentrations were strontium (median 549 micrograms per liter $[\mu \mathrm{g} / \mathrm{L}]$ ), iron (median $143 \mu \mathrm{g} / \mathrm{L}$ ), boron (median $35 \mu \mathrm{g} / \mathrm{L}$ ), and manganese (median $31.1 \mu \mathrm{g} / \mathrm{L}$ ). Concentrations of several trace elements, including boron, copper, iron, manganese, and strontium, were higher in samples from bedrock wells than those from sand and gravel wells. The highest radon-222 activities were in samples from bedrock wells (maximum 1,360 pCi/L); 44 percent of all samples exceeded a proposed U.S. Environmental Protection Agency drinking water standard of $300 \mathrm{pCi} / \mathrm{L}$. Nine pesticides and pesticide degradates were detected in six samples at concentrations of $0.42 \mu \mathrm{g} / \mathrm{L}$ or less; all were herbicides or their degradates, and most were degradates of alachlor, atrazine, and metolachlor. Six volatile organic compounds were detected in four samples at concentrations of $0.8 \mu \mathrm{g} / \mathrm{L}$ or less, including four trihalomethanes, tetrachloroethene, and toluene; most 
detections were in sand and gravel wells and none of the concentrations exceeded drinking water standards. Coliform bacteria were detected in six samples but fecal coliform bacteria, including Escherichia coli, were not detected in any sample.

\section{Introduction}

The Federal Clean Water Act Amendments of 1977 require that States monitor and report biennially on the chemical quality of surface water and ground water within their boundaries (U.S. Environmental Protection Agency, 1997, Section 305(b)). In 2002, the U.S. Geological Survey (USGS), in cooperation with the New York State Department of Environmental Conservation (NYSDEC), developed a program to evaluate ground-water quality throughout the major river basins in New York State on a rotating basis. The work parallels the NYSDEC Rotating Intensive Basin Study program, which evaluates surface-water quality in two or three of the 14 major river basins in the State each year. The ground-water quality program began in 2002 with a pilot study in the Mohawk River Basin (Butch and others, 2003). Sampling was completed in the Chemung River Basin in 2003 (Hetcher-Aguila, 2005); the Lake Champlain and Susquehanna River Basins in 2004 (Nystrom, 2006; Hetcher-Aguila and Eckhardt, 2006); and the St. Lawrence (Nystrom, 2007a), Delaware (Nystrom, 2007b), and Genesee River Basins (Eckhardt and others, 2007) in 2005. In 2006, ground water was sampled in the Mohawk River Basin, Niagara River Basin, Allegheny River Basin, Lake Erie tributaries, and western Lake Ontario tributaries. The Mohawk River Basin study, the subject of this report, entailed collection of 13 samples from surficial deposits and 14 samples bedrock, from August through November of 2006.

\section{Purpose and Scope}

This report presents the results of the 2006 ground-water quality study in the Mohawk River Basin. It (1) describes the methods of site selection, sample collection, and chemical analysis, and (2) presents the analytical results for physical properties, major ions, nutrients, trace elements and radionuclides, pesticides, volatile organic compounds (VOCs), and bacteria. Information about the sampled wells and results of the analyses are presented in tables A1 through A9, by constituent type, at the end of the report.

\section{Hydrogeologic Setting}

The Mohawk River Basin covers about 3,500 $\mathrm{mi}^{2}$ in central New York State (fig. 1). It encompasses parts of 14 counties, including all of Montgomery County, most of Schoharie and Schenectady Counties, parts of Herkimer, Hamilton, Fulton, Greene, Oneida, Saratoga, and Albany Counties, and small parts of Lewis, Madison, Otsego, and Delaware Counties. The Mohawk River is a major tributary to the Hudson River; the major tributaries to the Mohawk River are the Schoharie and West Canada Creeks (fig. 1). The Erie Canal was built along the Mohawk River as a major corridor for cargo transport; it was begun in 1817 and completed in 1825. Modernizations moving much of the canal into the river channel were completed in 1918 and the canal was renamed the New York State Barge Canal; currently the canal is used mostly for recreation. The Mohawk River Basin contains three major reservoirs (fig. 1): the Schoharie Reservoir, which diverts water out of the basin as part of New York City's water-supply system; Hinckley Reservoir, which provides drinking water to the Utica area, and Delta Reservoir. 


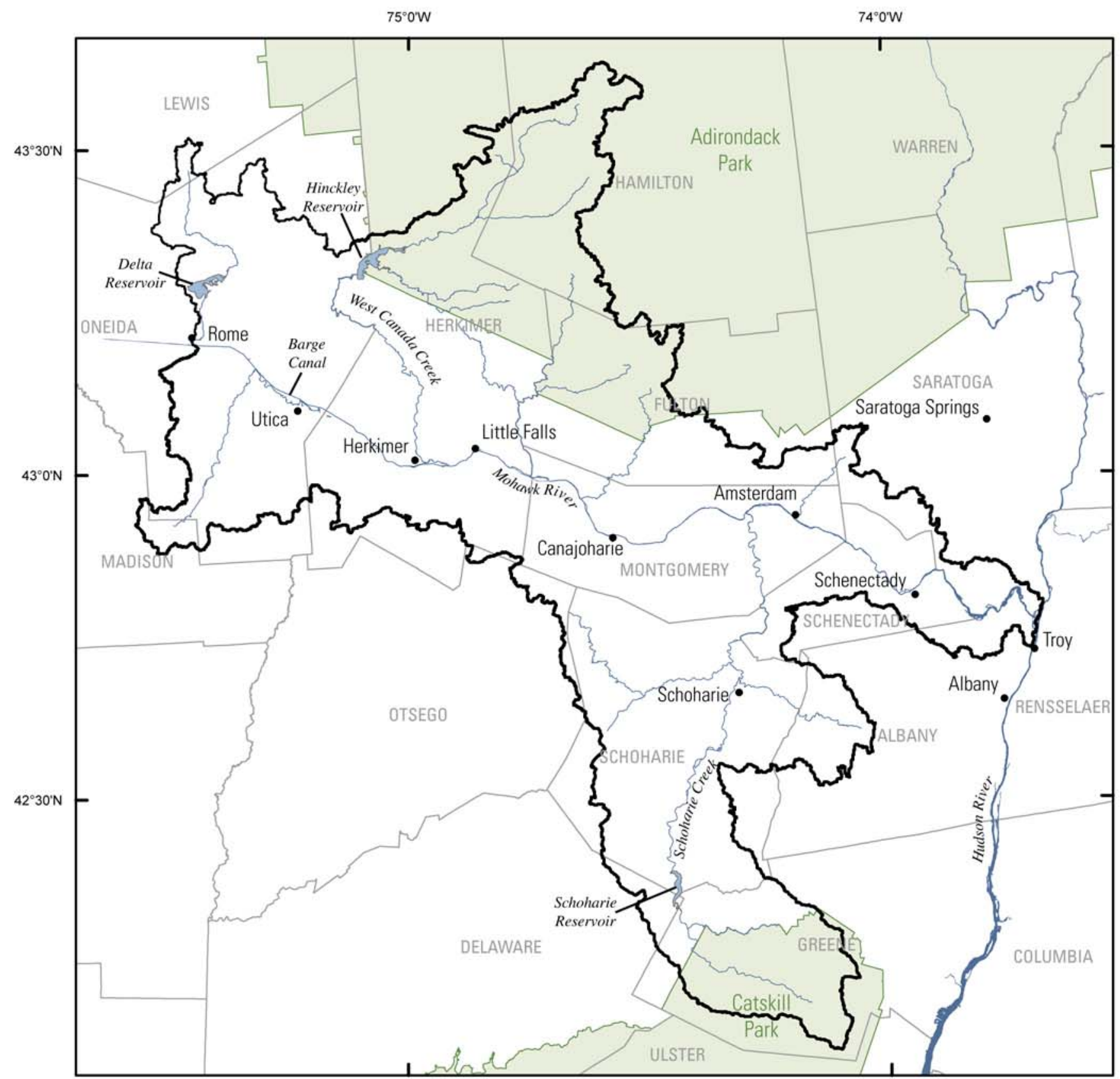

Base from U.S. Geolocical Survey digital data, 1983, 1:100,000 Universal Transverse Mercator projection

Zone 18

Figure 1. Hydrologic and geographic features and location

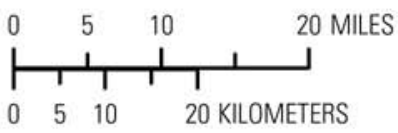
of the Mohawk River Basin in Central New York.

\section{EXPLANATION}

State park

Basin boundary

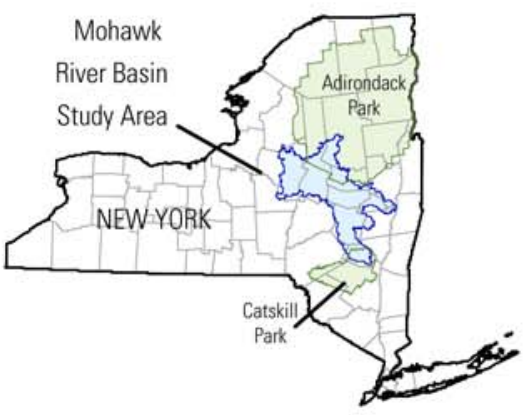


The Mohawk River Basin contains three main physiographic regions (fig. 2); these are (1) the Mohawk Valley, which extends eastward from the Great Lakes Lowland to the Hudson Valley through the center of the basin, (2) the Adirondack Mountain Upland, which spans the northern part of the basin, and (3) the Appalachian Upland, which spans the southern portion of the basin and includes parts of the Catskill Mountains. The highest elevations in the northern part of the (about 3,600 ft above sea level) are in the Adirondack Mountains Upland and the highest elevations in the southern end of the Basin are in the Catskill Mountain area (about 4,000 ft). The areas with the highest elevations also receive the most precipitation; the northern, northwestern, and southern parts of the basin receive more than 50 in/yr (Randall, 1996). Land use (fig. 3) also corresponds to the physiography of the basin; agriculture is concentrated along the Mohawk River and the northern part of Schoharie Creek, and the largest urban centers in the basin, including Utica, Amsterdam, and Schenectady (fig. 1), are within the Mohawk Valley; smaller urban areas in the Appalachian Upland to the south are present in the valleys of the Catskills region. The upland areas of the basin are predominantly forested (Vogelmann and others, 2001). Parts of the Adirondack and Catskill State Parks lie within the basin. The Adirondack State Park, created in 1892, contains about 6 million acres; about 6 percent of which is in the Mohawk River Basin. The Catskill Park was created in 1904 and encompasses about 700,000 acres, about 15 percent of which is in the basin.

Most of the Mohawk River Basin is underlain by sedimentary bedrock (fig. 4). The Mohawk Valley is underlain by shale, sandstone, and carbonate rocks of Upper to Middle Ordovician age (Isachsen and others, 2000). Outcrops of Cambrian rock are present at isolated locations; for example, at Little Falls (fig. 1). The southern part of the basin is underlain by interlayered sandstone and shale of Middle to Upper Devonian age. The northern part of the Basin is underlain by crystalline metamorphic bedrock of Precambrian age consisting mainly of gneisses. Of the bedrock aquifers in the basin, carbonate rocks generally produce the highest yields, and the crystalline bedrock generally has the lowest; the sandstone and shale aquifers generally have low to moderate yields (Hammond and others, 1978).

The surficial material throughout the basin was deposited primarily during the Pleistocene epoch, when the Wisconsin glaciers covered most of the Northeast. Till of low permeability was deposited by glaciers over most of the basin; wells finished in till generally have low yields. Sand and gravel including alluvium, outwash, and ice-contact deposits, form the most productive aquifers in the basin; wells finished in these deposits may yield as much as 1,000 gallons per minute (Phillips and Hanchar, 1996).

\section{Methods of Investigation}

The methods used in this study, including well-selection criteria, sampling methods, and analytical methods, were designed to maximize data precision, accuracy, and comparability to other studies. Sample collection and processing were conducted in accordance with standard USGS procedures (U.S. Geological Survey, variously dated). Samples were analyzed at three laboratories--the USGS National Water Quality Laboratory (NWQL) in Denver, Colo., the USGS Organic Geochemistry Research Laboratory (OGRL) in Lawrence Kans., and a New York State Department of Health (NYSDOH)-certified laboratory. All procedures were done in accordance with documented methods. 


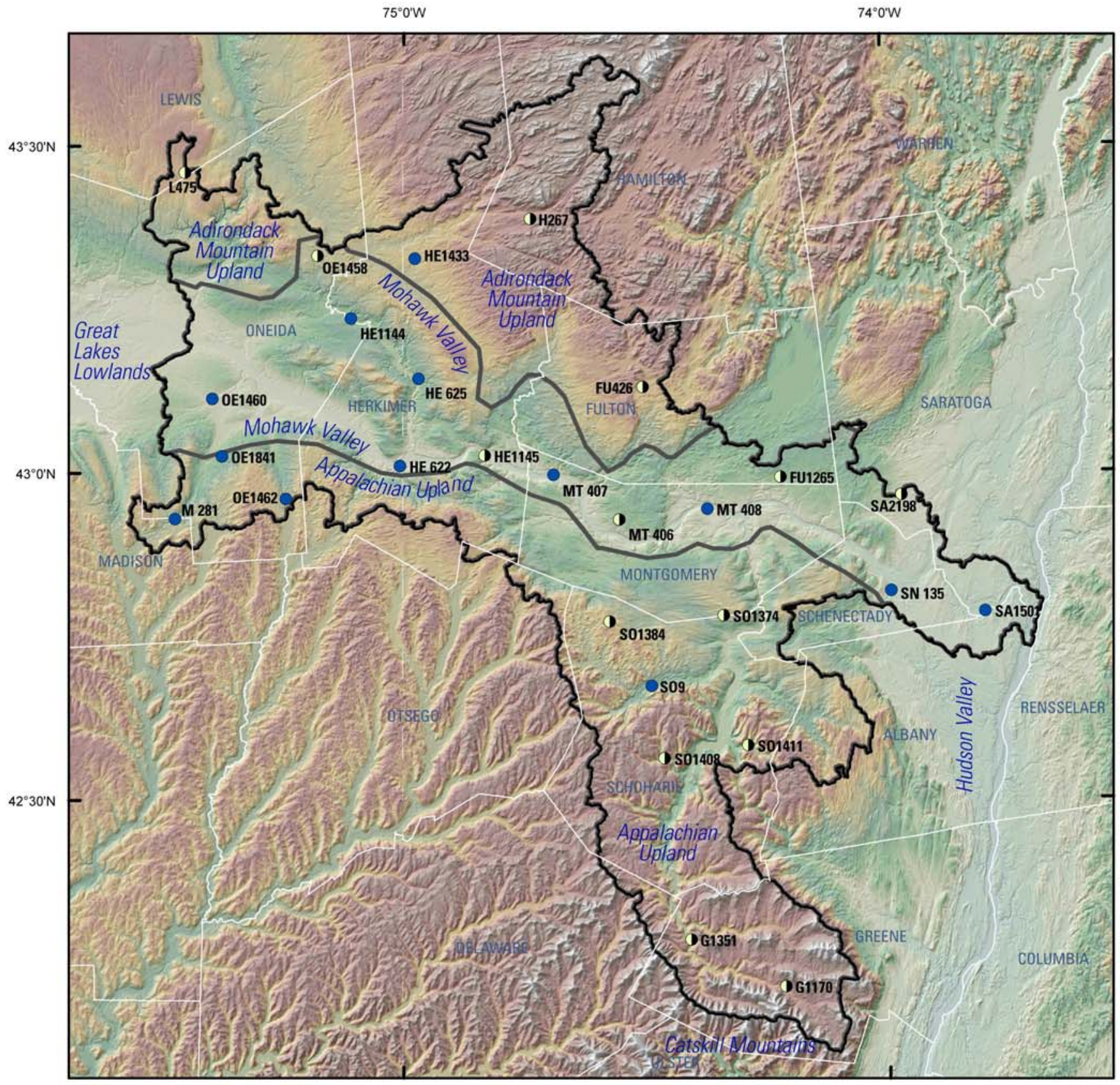

Base from U.S. Geolocical Survey digital data, 1983, 1:100,000 Universal Transverse Mercator projection

Elevations from National Elevation Dataset, 2005 Zone 18

Figure 2. Topography, physiographic regions, and locations

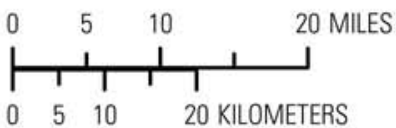
of wells sampled in the Mohawk River Basin.

\section{EXPLANATION}

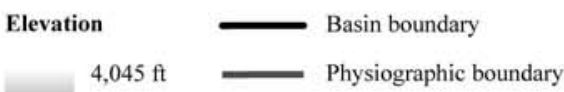

Wells sampled

- Sand and gravel

- Bedrock 


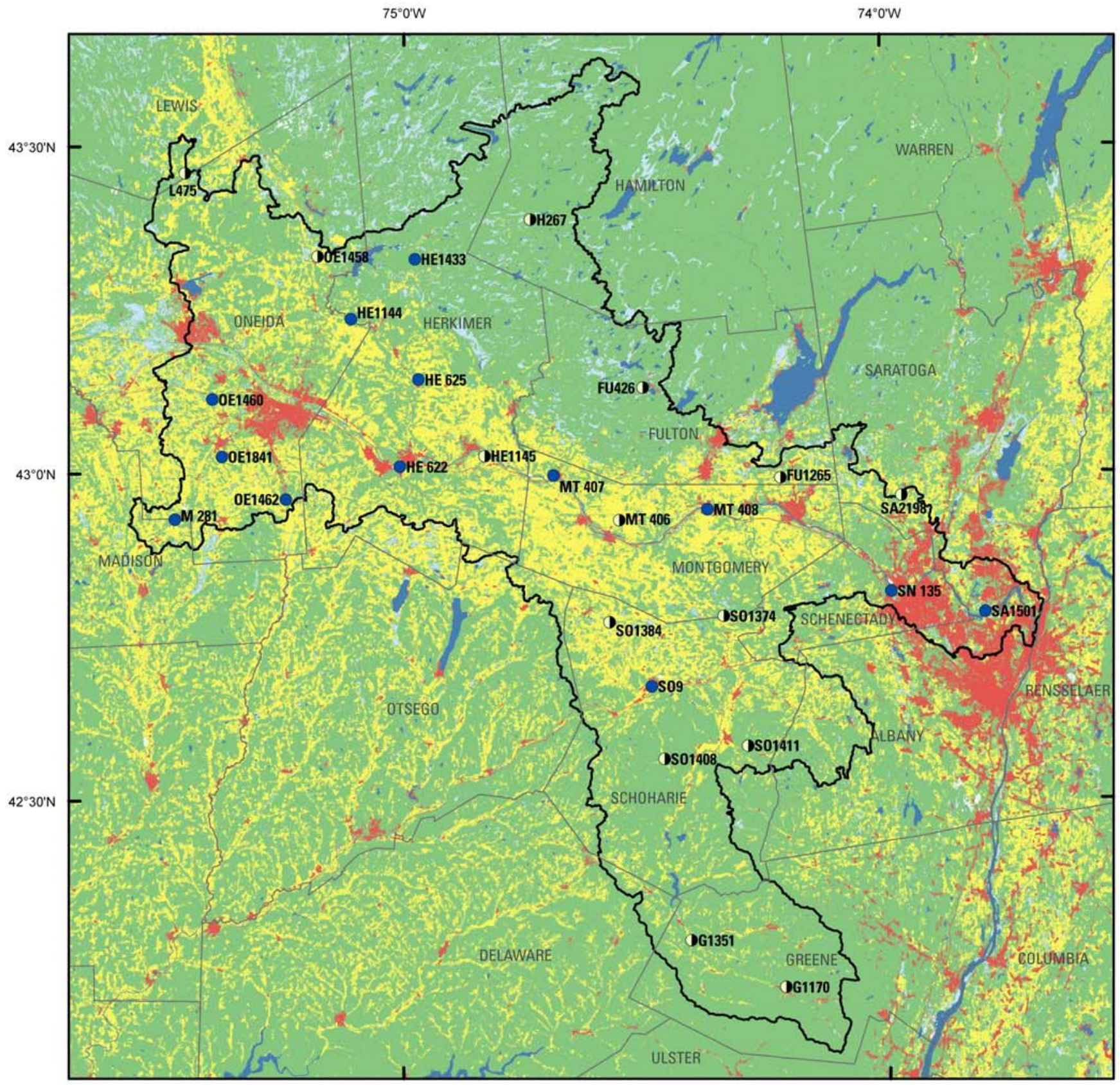

Base from U.S. Geolocical Survey digital data, 1983, 1:100,000 Universal Transverse Mercator projection

Land cover from Vogelmann and others, 2001

Zone 18

Figure 3. Land cover and locations of wells sampled in the Mohawk River Basin.

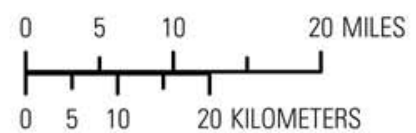

\section{EXPLANATION}

Land cover

- Basin boundary

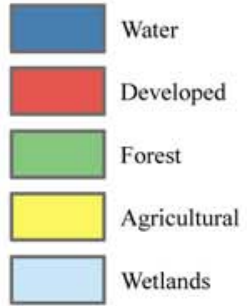

\section{Wells sampled}

Sand and gravel

- Bedrock 


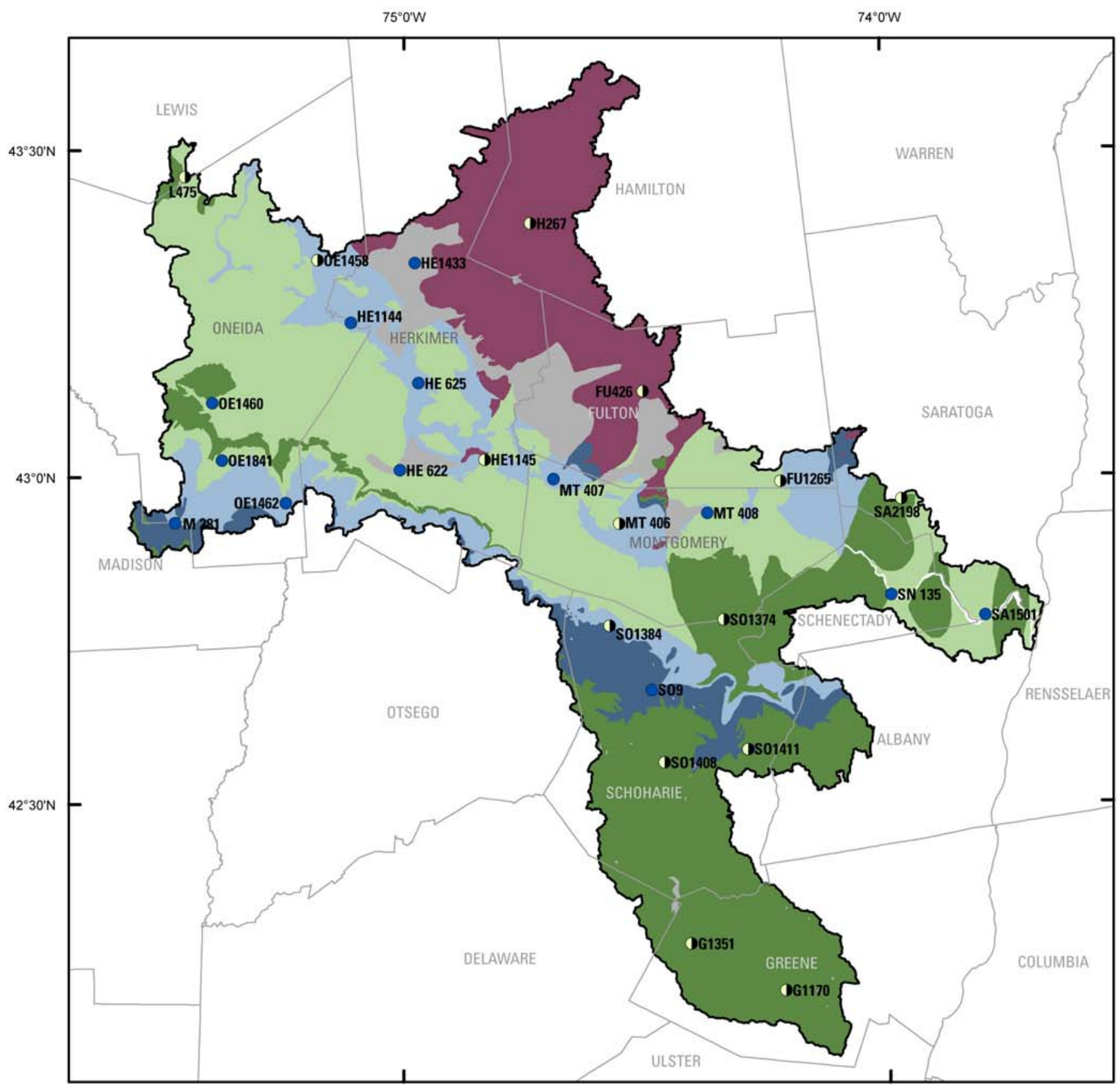

Base from U.S. Geolocical Survey digital data, 1983, 1:100,000 Universal Transverse Mercator projection

Geology modified from Fisher and others, 1970 Zone 18

Figure 4. Generalized bedrock geology and locations of wells sampled in the Mohawk River Basin.

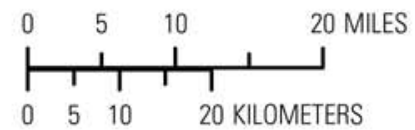

\section{EXPLANATION}

Bedrock

Basin boundary

\begin{tabular}{|l|l}
\hline $\begin{array}{l}\text { Carbonate rock } \\
\text { Shale, sandstone, } \\
\text { and carbonate }\end{array}$ \\
\hline Shale and sandstone \\
\hline Shale \\
\hline Crystalline \\
\hline $\begin{array}{l}\text { Unknown (covered by } \\
\text { glacial deposits) }\end{array}$ \\
\hline
\end{tabular}

Wells sampled

- Sand and gravel

- Bedrock 


\section{Site Selection}

Wells were selected to provide sufficient spatial coverage of the basin, with emphasis on areas

of greatest ground-water use. Selection also was based on the availability of well-construction data and hydrogeologic information on each well and its surrounding area. The study did not target specific municipalities, industries, or agricultural practices; rather, the 27 wells selected for sampling represented a combination of forested, rural, residential, and agricultural areas. Locations of the wells are shown in figures 2 and 3; the characteristics of the wells sampled and the types of land cover surrounding each well are listed in table A1 (at end of report). The depths and geologic units from which samples were collected, and the numbers of production and domestic wells are summarized below.

\begin{tabular}{lccc}
\hline & \multicolumn{3}{c}{ Number of wells } \\
\cline { 2 - 4 } Material in which well is completed & Production & Domestic & Total \\
\hline \hline Sand and gravel & $\mathbf{1 0}$ & $\mathbf{3}$ & $\mathbf{1 3}$ \\
$\quad$ Depth range: $22.5-190$ feet & & & \\
$\quad$ Bedrock & $\mathbf{2}$ & $\mathbf{1 2}$ & $\mathbf{1 4}$ \\
$\quad$ Depth range: $75-815$ feet & 1 & 3 & 4 \\
$\quad$ Carbonate & 1 & 3 & 4 \\
$\quad$ Shale & & 5 & 5 \\
$\quad$ Interlayered sandstone and shale & & 1 & 1 \\
$\quad$ Gneiss & $\mathbf{1 2}$ & $\mathbf{1 5}$ & $\mathbf{2 7}$ \\
\hline Total no. of wells & &
\end{tabular}

Land use within a half-mile radius of most wells was typically forested but other types of land use prevailed at some wells; for example well MT406 represents agricultural land, and well S09 is in a developed are (table A1).

Selection of the 15 domestic wells was based on information from the New York State Department of Environmental Conservation (NYSDEC) Water Well program, which began in 2000. The program requires that licensed well drillers file a report with NYSDEC containing basic information about each well drilled — such as well and casing depth and diameter, yield, and a hydrogeologic log. Inspection of well-completion reports identified about 200 wells as potential sampling sites. The well owners were sent a letter that included a request for permission to sample the well, and a questionnaire about the well. Well owners who granted permission were contacted later by phone to verify well information and arrange a convenient time for sampling.

Of the 12 production wells that were sampled, 11 had been previously sampled in 2002 as part of the initial study for this project. The additional production well was identified through the USGS Ground-Water Site Inventory (GWSI) database. Town officials and (or) water managers were sent letters requesting permission to sample a well, and follow-up phone calls were made to arrange a time for sampling. Well information that was not already in the data base, such as depth, was provided by water managers. The type of aquifer tapped by production and domestic wells was verified through published geologic maps, such as Fisher and others (1970). 


\section{Sampling Methods}

Ground-water samples were collected from August through November 2006 and processed through standard USGS protocols (U.S. Geological Survey, variously dated). The domestic-well samples were collected from a spigot between the well and pressure tank, where possible, and ahead of any water-treatment system so that they would be representative of the water quality within the aquifer. Production wells were sampled at the spigot or faucet used for collection of raw-water samples by water managers.

One or two wells were sampled per day. Typically, samples were collected through one or more 10-ft lengths of Teflon tubing attached to the garden-hose spigot closest to the well. After the tubing was connected, the well was purged by discharging to waste for at least 20 minutes, or until at least one well-casing volume of water had passed the sampling point. Most of the production wells were pumped for at least 1 hour before sampling, typically at pumping rates of about $100 \mathrm{gal} / \mathrm{min}$. Domestic wells were purged at pumping rates ranging from about 5 to $10 \mathrm{gal} / \mathrm{min}$; wells that had been recently used were purged of amounts less than three well-casing volumes. Notes about the well and surrounding land and land use were taken during well purging, and a global positioning system (GPS) measurement of latitude and longitude was recorded. After the well was purged, water was directed at $1 \mathrm{gal} / \mathrm{min}$ or less into a flow-through chamber that contained a meter with temperature, $\mathrm{pH}$, specific conductance, and dissolved-oxygen sensors. Field values were then recorded at regular intervals; sampling began when the values of temperature, $\mathrm{pH}$, specific conductance, and dissolved oxygen concentration had stabilized (U.S. Geological Survey, variously dated).

The flow rate for sampling was adjusted to about $0.5 \mathrm{gal} / \mathrm{min}$ or less. The Teflon sampling tube was then disconnected from the multi-probe meter and connected to a sampling chamber consisting of a polyvinyl chloride (PVC) frame and a clear-plastic chamber bag. The sampling chamber was placed on a table with a built-in drain constructed from a plastic box. The Teflon tubing and spigot-attachment equipment were cleaned in the laboratory before each day of sampling with a dilute phosphate-free detergent solution, followed by tap water and deionized water rinses. Equipment for filtration of pesticide samples was rinsed with methanol. A new sampling-chamber bag was used at each site. Samples were collected and preserved in the sampling chamber according to standard USGS methods. Sample bottles for nutrient, major-ion, and some trace-element analyses were filled with water filtered through disposable (one-time use) $0.45-\mu \mathrm{m}$-pore-size polyether sulfone capsule filters that were preconditioned in the laboratory with deionized water on the day of sample collection. Sample bottles for pesticide analysis were filled with water filtered through baked $0.7-\mu \mathrm{m}$-pore-size glass fiber filters. Acid preservation was required for trace element, VOC, and major ion analyses. Acid preservative was added after collection of other samples was completed to avoid the possibility of cross contamination by the acid preservative; for example, samples preserved with nitric acid were acidified after the collection of samples for nutrient analysis. Samples for radon analysis were collected through a septum chamber with a glass syringe according to standard USGS procedures. All samples analyzed by NYSDOHcertified laboratories were collected in bottles provided by the analyzing laboratory. All samples except those for radiochemical analysis were chilled to $4{ }^{\circ} \mathrm{C}$ or less after collection and shipped by overnight delivery to the designated laboratories.

All but five sampling sites had easy access to a spigot; these five wells (HE622, MT406, SA1501, SN135, and SO9, fig. 2) were production wells and were sampled from taps or hydrants at which water-system personnel routinely collect raw-water samples. At these sites, physical properties were measured by the multisensor meter in a bucket; flow was adjusted to avoid air entrainment. The 
syringe for radon-222 sample collection at these sites was inserted directly into the flowing water in the throat of the tap or hydrant to minimize sample exposure to the atmosphere.

\section{Analytical Methods}

Samples were analyzed for 226 physical properties and constituents, including inorganic constituents, nutrients, trace elements, radionuclides, pesticides and their degradates, VOCs, and bacteria. Physical properties, namely water temperature, $\mathrm{pH}$, dissolved oxygen, and specific conductance were measured at the sampling site. Analyses for inorganic constituents, nutrients, trace elements, radon-222, pesticides and pesticide degradates, and VOCs were conducted at the USGS NWQL in Denver, Colo.; some additional pesticide and pesticide-degradate analyses were done at the USGS OGRL in Lawrence, Kans. The analyses for total organic carbon, phenolic compounds, and bacteria were done at Friend Laboratory in Waverly, N.Y., a NYSDOH-certified laboratory.

Anion concentrations were measured by ion-exchange chromatography; cation concentrations were measured by inductively coupled plasma-atomic emission spectrometry (ICP-AES), as described in Fishman (1993). Nutrients concentrations were measured through colorimetry, as described by Fishman (1993), and through Kjeldahl digestion with photometric finish, as described by Patton and Truitt (2000). Mercury concentrations were measured by cold vapor-atomic fluorescence spectrometry according to methods described by Garbarino and Damrau (2001). Arsenic, chromium, and nickel concentrations were measured through collision/reaction cell inductively coupled plasma-mass spectrometry (cICPMS) as described by Garbarino and others (2006). Remaining trace-element analyses were done by ICP-AES (Struzeski and others, 1996), inductively coupled plasma-optical emission spectrometry (ICP-OES), and inductively coupled plasma-mass spectrometry (ICP-MS) (Garbarino and Struzeski, 1998). In-bottle digestions for trace-element analyses were done as described by Hoffman and others (1996). Radon-222 concentrations were measured through liquid-scintillation counting (ASTM International, 2006).

Samples for pesticide analyses were processed as described by Wilde and others (2004). Pesticides and pesticide-degradates were analyzed at the NWQL through gas chromatography-mass spectrometry (GC-MS) and high-performance liquid chromatography-mass spectrometry (HPLC-MS) as described by Zaugg and others (1995), Sandstrom and others (2001), and Furlong and others (2001). Acetamide parent compounds and degradation-product analyses were conducted through liquid chromatography-mass spectrometry (LC-MS) at the USGS OGRL according to methods described by Lee and Strahan (2003). The VOC analyses were done through GC-MS by methods described by Connor and others (1998).

Total organic carbon concentration was measured by method SW-846 9060 (U.S. Environmental Protection Agency, 2004), and total phenolic compounds were measured by USEPA method 420.2 (U.S. Environmental Protection Agency, 1983). Bacterial samples were collected in accordance with NYSDEC and NYSDOH protocols, except that the tap from which each water sample was collected was not flame sterilized. Samples were tested for total coliform, fecal coliform, and Escherichia coli (E. coli) by Standard Methods 9222 B, D, and G (American Public Health Association, 1998). Results for fecal coliform analysis are reported as estimated because the samples could not reach the laboratory within the 6-hour holding time; the remaining samples were processed within holding times. A heterotrophic plate count test (SM 9215 B) also was conducted. 
One blank sample and two sequential replicate samples were collected for quality assurance in addition to the 27 well-water samples. Nitrogen-purged VOC/pesticide-grade blank water and inorganic-grade blank water supplied by the USGS NWQL were used for an equipment blank; the water was run through a part of the Teflon tubing used for sampling, and water for filtered-water constituents was pumped through cleaned, pre-conditioned filters. Quality assurance samples were acidified in the same manner as environmental samples. No constituents were detected at concentrations above laboratory reporting levels in the blank. The percent-concentration differences from the sequential replicate sample were less than 5 percent for most of the constituents detected in the replicate samples; the largest percent differences were in trace elements whose concentrations were less than or near the reporting level.

\section{Ground-Water Quality}

More than half (159) of the 226 constituents or properties for which ground-water samples were analyzed were not detected in any sample at a concentration exceeding laboratory reporting levels (table A2). Concentrations of the 67 constituents and properties that were detected are reported in tables A3 through A9. The concentrations of some constituents are listed in these tables as "estimated" (preceded by letter E); estimated values are typically reported where the detected value is less than the established laboratory reporting levels, or when recovery of a compound has been shown to be highly variable (Childress and others, 1999). Concentrations of some constituents exceeded maximum contaminant levels (MCLs) or secondary drinking water standards (SDWS) set by the U.S. Environmental Protection Agency (USEPA) (U.S. Environmental Protection Agency, 2003) or NYSDOH (New York State Department of Health, 2007). MCLs are enforceable standards for finished water at public water supplies; although they are not enforceable for private homeowner wells, they are presented here as a standard for evaluation of the water-quality results. Secondary drinking water standards typically relate to corrosivity or aesthetic concerns such as taste, odor, or staining of plumbing fixtures and are not enforceable.

\section{Physical Properties}

Sample color ranged from $<1$ to $20 \mathrm{Pt}$-Co units; the median was $2 \mathrm{Pt}$-Co units (table A3). The color of one sample, $20 \mathrm{Pt}-\mathrm{Co}$ units, exceeded the NYSDOH MCL and USEPA SDWS of $15 \mathrm{Pt}-\mathrm{Co}$ units. Dissolved oxygen concentration from $<0.1$ to $12.2 \mathrm{mg} / \mathrm{L}$ and was generally greater in samples from sand and gravel wells (median $5.6 \mathrm{mg} / \mathrm{L}$ ) than in samples from bedrock wells (median $0.2 \mathrm{mg} / \mathrm{L}$ ). Sample $\mathrm{pH}$ ranged from 6.1 to 8.7; the median $\mathrm{pH}$ was 7.2 in samples from sand and gravel wells and 7.7 in samples from bedrock wells. The $\mathrm{pH}$ of two samples, 6.1 and 8.7, exceeded the USEPA SDWS range for $\mathrm{pH}, 6.5$ to 8.5 . Specific conductance ranged from 32 to $2,230 \mu \mathrm{S} / \mathrm{cm}$ at $25^{\circ} \mathrm{C}$ with a median of $670 \mu \mathrm{S} / \mathrm{cm} @ 25^{\circ} \mathrm{C}$. Water temperature ranged from 8.5 to $14.5^{\circ} \mathrm{C}$ with a median temperature of $11.0^{\circ} \mathrm{C}$.

\section{Major lons}

The anion with the highest concentrations was bicarbonate (tables 1 and A4), with a median concentration of $276 \mathrm{mg} / \mathrm{L}$. The cations with the highest concentrations were calcium (median 58.9 $\mathrm{mg} / \mathrm{L}$ ) and sodium (median $41.9 \mathrm{mg} / \mathrm{L}$ ). The concentration of sodium in 11 samples exceeded the 
USEPA nonregulatory drinking water advisory taste threshold of $60 \mathrm{mg} / \mathrm{L}$; the maximum concentration of sodium was $662 \mathrm{mg} / \mathrm{L}$. The concentration of chloride in two samples, 1,070 and $600 \mathrm{mg} / \mathrm{L}$, exceeded the NYSDOH MCL of $250 \mathrm{mg} / \mathrm{L}$. The concentrations of sodium and chloride were generally higher in samples from bedrock wells than in samples from sand and gravel wells, as shown in table 1, and were elevated in samples from three bedrock wells--G1170, G1351, and SO1374. The concentration of fluoride in one sample, $2.8 \mathrm{mg} / \mathrm{L}$, exceeded the NYSDOH MCL of $2.2 \mathrm{mg} / \mathrm{L}$ but did not exceed the USEPA MCL of $4.0 \mathrm{mg} / \mathrm{L}$. The concentration of sulfate in one sample, $451 \mathrm{mg} / \mathrm{L}$, exceeded the USEPA SDWS and NYSDOH MCL of $250 \mathrm{mg} / \mathrm{L}$.

Water hardness in the samples ranged from 23 to $510 \mathrm{mg} / \mathrm{L}$ as $\mathrm{CaCO}_{3}$, and was typically very hard $\left(180 \mathrm{mg} / \mathrm{L}\right.$ or more as $\mathrm{CaCO}_{3}$; Hem, 1985); the median hardness was $230 \mathrm{mg} / \mathrm{L}$ as $\mathrm{CaCO}_{3}$. Nine of the 13 samples from the Mohawk Valley were very hard, whereas, all four samples from the Adirondack Uplands were soft ( $60 \mathrm{mg} / \mathrm{L}$ of $\mathrm{CaCO}_{3}$ or less). Concentrations of calcium and magnesium (and therefore water hardness), were generally greater in samples from sand and gravel wells than from those from bedrock wells. Alkalinity ranged from 34 to $367 \mathrm{mg} / \mathrm{L}$ as $\mathrm{CaCO}_{3}$, with a median of $226 \mathrm{mg} / \mathrm{L}$ as $\mathrm{CaCO}_{3}$; it was highest in areas with carbonate bedrock and lowest in areas with crystalline bedrock. Residue on evaporation at $180^{\circ} \mathrm{C}$, a measurement of total dissolved solids, ranged from 57 to 1,920 $\mathrm{mg} / \mathrm{L}$ with a median of $409 \mathrm{mg} / \mathrm{L}$; the highest values were in samples from bedrock wells.

Table 1. Drinking water standards and summary statistics for concentrations of major ions in groundwater samples from the Mohawk River Basin, 2006.

[All concentrations in milligrams per liter in filtered water except as noted; --, not applicable; <, less than]

\begin{tabular}{|c|c|c|c|c|c|c|c|c|c|}
\hline & & & \multirow{3}{*}{$\begin{array}{c}\text { No. of } \\
\text { Samples } \\
\text { exceeding } \\
\text { standard }\end{array}$} & \multicolumn{6}{|c|}{$\begin{array}{ll}\text { Concentration } \\
\end{array}$} \\
\hline & & \multirow{2}{*}{$\begin{array}{l}\text { Drinking } \\
\text { Water } \\
\text { Standard }\end{array}$} & & \multicolumn{3}{|c|}{$\begin{array}{c}\text { Sand and gravel aquifers } \\
\text { (13 samples) }\end{array}$} & \multicolumn{3}{|c|}{$\begin{array}{c}\text { Bedrock aquifers } \\
\text { (14 samples) }\end{array}$} \\
\hline & & & & Minimum & Median & Maximum & Minimum & Median & Maximum \\
\hline \multirow{4}{*}{ : } & Calcium & -- & -- & 15.8 & 63.9 & 132 & 5.87 & 24.8 & 123 \\
\hline & Magnesium & -- & -- & 1.95 & 17.0 & 57.0 & 1.08 & 6.14 & 53.7 \\
\hline & Potassium & -- & -- & .50 & 1.29 & 3.99 & .56 & 1.52 & 7.38 \\
\hline & Sodium & $60^{\mathrm{a}}$ & 11 & 1.48 & 15.2 & 73.6 & 4.12 & 83.6 & 662 \\
\hline \multirow{4}{*}{$\frac{n}{0}$} & Bicarbonate & -- & -- & 55 & 288 & 394 & 41 & 245 & 448 \\
\hline & Chloride & $250^{\mathrm{b}}$ & 2 & 1.85 & 27.3 & 150 & .31 & 65.1 & 1,070 \\
\hline & Fluoride & $2.2^{\mathrm{b}}$ & 1 & $<.1$ & .1 & .5 & .1 & .4 & 2.8 \\
\hline & Sulfate & $250^{\mathrm{bc}}$ & 1 & 4.4 & 21.5 & 99.5 & $<.9$ & 11.9 & 451 \\
\hline \multicolumn{4}{|c|}{ Hardness, unfiltered, mg/L as $\mathrm{CaCO}_{3}$} & 47 & 300 & 400 & 23 & 85 & 510 \\
\hline \multicolumn{4}{|c|}{ Alkalinity, filtered, $\mathrm{mg} / \mathrm{L}$ as $\mathrm{CaCO}_{3}$} & 45 & 236 & 323 & 34 & 201 & 367 \\
\hline \multicolumn{4}{|c|}{ Residue on evaporation, filtered, $\mathrm{mg} / \mathrm{L}$} & 72 & 334 & 627 & 57 & 509 & 1,920 \\
\hline
\end{tabular}




\section{Nutrients and Organic Carbon}

Concentrations of nutrients varied with well depth and aquifer type. Concentrations of nitrate and organic carbon were generally higher in wells finished in sand and gravel than in those finished in bedrock, as shown below in table 2. Concentrations of nitrate ranged from $<0.06$ to $2.6 \mathrm{mg} / \mathrm{L}$ as N (tables 2 and A5); the median concentration was $0.28 \mathrm{mg} / \mathrm{L}$ as $\mathrm{N}$ in samples from sand and gravel wells and $<0.06 \mathrm{mg} / \mathrm{L}$ as $\mathrm{N}$ in samples from bedrock wells. Nitrite was detected in only two sand and gravel wells with a maximum concentration of $0.003 \mathrm{mg} / \mathrm{L}$ as $\mathrm{N}$. No concentrations of nitrate or nitrite exceeded established MCLs of the USEPA or NYSDOH $(10 \mathrm{mg} / \mathrm{L}$ as $\mathrm{N}$ and $1 \mathrm{mg} / \mathrm{L}$ as $\mathrm{N}$, respectively). Organic carbon was detected in samples from 7 of the 13 sand and gravel wells with a median concentration of $1 \mathrm{mg} / \mathrm{L}$ and a maximum of $1.6 \mathrm{mg} / \mathrm{L}$; organic carbon was not detected in any samples from bedrock wells (reporting level $1 \mathrm{mg} / \mathrm{L}$ ).

Concentrations of ammonia and orthophosphate were generally higher in samples from bedrock wells than in samples from sand and gravel wells. The concentration of ammonia ranged from $<0.010$ to $1.88 \mathrm{mg} / \mathrm{L}$ as $\mathrm{N}$; the median concentration was $0.349 \mathrm{mg} / \mathrm{L}$ as $\mathrm{N}$ in samples from bedrock wells and estimated $0.006 \mathrm{mg} / \mathrm{L}$ as $\mathrm{N}$ in samples from sand and gravel wells. Orthophosphate concentrations ranged from estimated 0.004 to $0.143 \mathrm{mg} / \mathrm{L}$ as $\mathrm{P}$; the median concentration in samples from bedrock wells was $0.018 \mathrm{mg} / \mathrm{L}$ as $\mathrm{P}$; the median in samples from sand and gravel wells was $0.007 \mathrm{mg} / \mathrm{L}$ as $\mathrm{P}$.

Table 2. Drinking water standards and summary statistics for concentrations of nutrients in groundwater samples from the Mohawk River Basin, 2006.

[All concentrations in filtered water except as noted; --, not applicable; $<$, less than]

\begin{tabular}{|c|c|c|c|c|c|c|c|c|}
\hline & & & \multicolumn{6}{|c|}{ Concentration } \\
\hline & \multirow{2}{*}{$\begin{array}{c}\text { Drinking } \\
\text { Water } \\
\text { Standard }\end{array}$} & \multirow{2}{*}{$\begin{array}{c}\text { No. of } \\
\text { Samples } \\
\text { exceeding } \\
\text { standard }\end{array}$} & \multicolumn{3}{|c|}{$\begin{array}{c}\text { Sand and gravel wells } \\
\text { (13 samples) }\end{array}$} & \multicolumn{3}{|c|}{$\begin{array}{l}\text { Bedrock wells } \\
\text { (14 samples) }\end{array}$} \\
\hline & & & Minimum & Median & Maximum & Minimum & Median & Maximum \\
\hline Ammonia plus organic $\mathrm{N}, \mathrm{mg} / \mathrm{L}$ as $\mathrm{N}$ & -- & -- & $<0.10$ & 0.06 & 1.2 & $<0.1$ & 0.36 & 2.1 \\
\hline Ammonia, $\mathrm{mg} / \mathrm{L}$ as $\mathrm{N}$ & -- & -- & $<.010$ & E.006 & 1.02 & .005 & .349 & 1.88 \\
\hline Nitrite plus nitrate, $\mathrm{mg} / \mathrm{L}$ as $\mathrm{N}$ & $10^{\mathrm{ab}}$ & 0 & $<.06$ & .28 & 2.6 & $<.06$ & $<.06$ & .6 \\
\hline Nitrite, $\mathrm{mg} / \mathrm{L}$ as $\mathrm{N}$ & $1^{\mathrm{ab}}$ & 0 & $<.002$ & $<.002$ & .003 & $<.002$ & $<.002$ & $<.002$ \\
\hline Orthophosphate, $\mathrm{mg} / \mathrm{L}$ as $\mathrm{P}$ & -- & -- & E.004 & .007 & .143 & .006 & .018 & .123 \\
\hline $\begin{array}{l}\text { Total organic carbon, unfiltered } \\
\text { sample, } \mathrm{mg} / \mathrm{L}\end{array}$ & -- & -- & $<1$ & 1 & 1.6 & $<1$ & $<1$ & $<1$ \\
\hline
\end{tabular}

${ }^{\text {a } U S E P A ~ M a x i m u m ~ C o n t a m i n a n t ~ L e v e l ~}$

${ }^{\mathrm{b}}$ NYSDOH Maximum contaminant level

\section{Trace Elements and Radionuclides}

The trace elements present in the highest concentrations were strontium (median $549 \mu \mathrm{g} / \mathrm{L}$ ), iron (median $143 \mu \mathrm{g} / \mathrm{L}$ in unfiltered water; $39 \mu \mathrm{g} / \mathrm{L}$ in filtered water), boron (median $35 \mu \mathrm{g} / \mathrm{L}$ ), and manganese (median 31.1 $\mu \mathrm{g} / \mathrm{L}$ in unfiltered water; $24.0 \mu \mathrm{g} / \mathrm{L}$ in filtered water) (tables 3 and A6). Median concentrations of boron, copper, iron, lithium, manganese and strontium were generally greater 
in samples from wells finished in bedrock than in those from wells finished in sand and gravel (table 3). The concentration of aluminum in two samples, 348 and $59 \mu \mathrm{g} / \mathrm{L}$, exceeded the USEPA SDWS range of 50 to $200 \mu \mathrm{g} / \mathrm{L}$. The concentration of arsenic in two samples, 17.8 and $16.4 \mu \mathrm{g} / \mathrm{L}$, exceeded the USEPA MCL of $10 \mu \mathrm{g} / \mathrm{L}$. The concentration of iron in 10 unfiltered and 6 filtered samples exceeded the USEPA SDWS and NYSDOH MCL of $300 \mu \mathrm{g} / \mathrm{L}$; the maximum concentration of iron was 8,190 $\mu \mathrm{g} / \mathrm{L}$ in an unfiltered sample. The concentration of manganese exceeded the USEPA SDWS of $50 \mu \mathrm{g} / \mathrm{L}$ in 10 unfiltered and 11 filtered samples and exceeded the NYSDOH MCL of 300 $\mu \mathrm{g} / \mathrm{L}$ in 3 filtered samples. No samples exceeded drinking water standards for antimony, barium, beryllium, cadmium, chromium, copper, lead, selenium, zinc, or uranium.

Radon-222 activities in the water samples ranged from 20 to $1,360 \mathrm{pCi} / \mathrm{L}$, with a median of 250 $\mathrm{pCi} / \mathrm{L}$. The highest radon activities $(600 \mathrm{pCi} / \mathrm{L}$ and greater) were in samples from bedrock wells. Radon concentration in drinking water is currently not regulated; however, the USEPA has proposed a two-part standard for drinking water: (1) a $300 \mathrm{pCi} / \mathrm{L}$ MCL for areas that do not implement an indoor air radon-mitigation program, and (2) an alternative MCL (AMCL) of 4,000 pCi/L for areas that do (U.S. Environmental Protection Agency, 1999). Activities in 12 of the samples (44 percent) exceeded the proposed MCL; none of the samples exceeded the proposed AMCL.

\section{Pesticides}

Nine pesticides were detected in six samples; all were herbicides or their degradates and most were degradates of the triazine and amide broadleaf herbicides atrazine, alachlor, and metolachlor (table A7). Pesticides were detected in samples from four sand and gravel wells and two bedrock wells. Most concentrations were on the order of hundredths or thousandths of micrograms per liter; the highest were metolachlor degradates (maximum $0.42 \mu \mathrm{g} / \mathrm{L}$ ). The most frequently detected pesticides were atrazine (4 samples), CIAT (2-chloro-4-isopropylamino-6-amino-s-triazine, 4 samples), and Metolachlor ESA (3 samples). No pesticide concentrations exceeded established drinking water standards; pesticide degradates are not currently regulated.

\section{Volatile Organic Compounds and Phenolic Compounds}

VOCs were detected in samples from four wells- three sand and gravel wells and one bedrock well (table A8). Six VOCs were detected, including, tetrachloroethene, toluene, and four trihalomethanes. Trihalomethanes (THMs) are disinfection byproducts that form when chlorine or bromine are used as disinfectants; they are also used as solvents. The THMs detected were bromodichloromethane, dibromochloromethane, tribromomethane (bromoform), and trichloromethane (chloroform). Three of the four THMs were detected in two samples each, the last was detected in three samples. The median concentration of detected THMs was $0.3 \mu \mathrm{g} / \mathrm{L}$, the maximum was $0.8 \mu \mathrm{g} / \mathrm{L}$. The USEPA and NYSDOH MCLs for total trihalomethanes (TTHMs) is $80 \mu \mathrm{g} / \mathrm{L}$; the maximum TTHMs in the samples was $2 \mu \mathrm{g} / \mathrm{L}$. Tetrachloroethene (PERC), a solvent sometimes used for dry cleaning, was detected in one sample at a concentration of $0.4 \mu \mathrm{g} / \mathrm{L}$; the USEPA and NYSDOH MCLs for tetrachloroethene are $5 \mu \mathrm{g} / \mathrm{L}$. Toluene, a component of gasoline, was detected in two wells at a concentration of $0.2 \mu \mathrm{g} / \mathrm{L}$; it was the only VOC detected in a sample from a bedrock well. The NYSDOH MCL for toluene is $5 \mu \mathrm{g} / \mathrm{L}$, and the USEPA MCL is $1,000 \mu \mathrm{g} / \mathrm{L}$. Phenolic compounds were detected in samples from three wells; the maximum concentration was $13 \mu \mathrm{g} / \mathrm{L}$. 
Table 3. Drinking water standards and summary statistics for concentrations of trace elements and radon-222 in ground-water samples from the Mohawk River Basin, 2006.

$[<$, less than; M, constituent detected but not quantified; --, not applicable. All concentrations are in micrograms per liter except as noted]

\begin{tabular}{|c|c|c|c|c|c|c|c|c|}
\hline & \multirow{3}{*}{$\begin{array}{l}\text { Drinking } \\
\text { Water } \\
\text { Standard }\end{array}$} & \multirow{3}{*}{$\begin{array}{c}\text { No. of } \\
\text { Samples } \\
\text { exceeding } \\
\text { standard } \\
\end{array}$} & \multicolumn{6}{|c|}{ Concentration } \\
\hline & & & \multicolumn{3}{|c|}{$\begin{array}{c}\text { Sand and gravel wells } \\
\text { (13 samples) }\end{array}$} & \multicolumn{3}{|c|}{$\begin{array}{l}\text { Bedrock wells } \\
\text { (14 samples) }\end{array}$} \\
\hline & & & Minimum & Median & Maximum & Minimum & Median & Maximum \\
\hline Aluminum, unfiltered & $50-200^{c}$ & $1-2$ & $<2$ & $<2$ & 18 & $<2$ & 6 & 348 \\
\hline Antimony, unfiltered & $6^{\mathrm{ab}}$ & 0 & $<.2$ & $<.2$ & $<.2$ & $<.2$ & $<.2$ & .4 \\
\hline Arsenic, unfiltered & $10^{\mathrm{a}}$ & 2 & .12 & .55 & 17.8 & .06 & .40 & 16.4 \\
\hline Barium, unfiltered & $2000^{\mathrm{ab}}$ & 0 & M & 58 & 916 & 4 & 100 & 475 \\
\hline Beryllium, unfiltered & $4^{\mathrm{ab}}$ & 0 & $<.06$ & $<.06$ & .03 & $<.06$ & $<.06$ & .04 \\
\hline Boron, filtered & & & 4.1 & 24 & 125 & $<7.0$ & 122 & 608 \\
\hline Cadmium, unfiltered & $5^{\mathrm{ab}}$ & 0 & $<.04$ & $<.04$ & .05 & $<.04$ & $<.04$ & .19 \\
\hline Chromium, unfiltered & $100^{\mathrm{ab}}$ & 0 & $<.60$ & $<.60$ & .88 & $<.60$ & .30 & 14.8 \\
\hline Cobalt, unfiltered & -- & -- & .028 & .173 & .742 & .023 & .108 & .556 \\
\hline Copper, unfiltered & $1000^{c}$ & 0 & 0.6 & 1.2 & 4.7 & .5 & 2.8 & 26.2 \\
\hline Iron, filtered & $300^{\mathrm{bc}}$ & 6 & $<6$ & 8 & 1,240 & $<6$ & 72 & 2,190 \\
\hline Iron, unfiltered & $300^{\mathrm{bc}}$ & 10 & $<6$ & 29 & 1,210 & 17 & 208 & 8,190 \\
\hline Lead, unfiltered & $15^{\mathrm{d}}$ & 0 & $<.06$ & .09 & 2.13 & $<.06$ & .12 & 2.21 \\
\hline Lithium, unfiltered & -- & -- & 1 & 5.7 & 75.7 & $<.6$ & 43.7 & 824 \\
\hline Manganese, filtered & $50^{c}$ & 11 & $<.6$ & 10.1 & 1,960 & $<.6$ & 37.1 & 306 \\
\hline Manganese, unfiltered & $50^{c}$ & 10 & $<.6$ & 18.1 & 2,020 & .5 & 47.8 & 306 \\
\hline Molybdenum, unfiltered & -- & -- & $<.2$ & .4 & 4.5 & $<.2$ & 2.3 & 10.4 \\
\hline Nickel, unfiltered & -- & -- & .24 & .76 & 2.29 & .17 & 1.03 & 2.48 \\
\hline Selenium, unfiltered & $50^{\mathrm{ab}}$ & 0 & $<.08$ & .04 & .71 & $<.08$ & $<.08$ & .40 \\
\hline Strontium, unfiltered & -- & -- & 30.2 & 369 & 2,640 & 30.0 & 608 & 31,100 \\
\hline Zinc, unfiltered & $5000^{\mathrm{bc}}$ & 0 & $<2$ & 3 & 10 & $<2$ & 2 & 16 \\
\hline Radon-222, unfiltered, $\mathrm{pCi} / \mathrm{L}$ & $300^{\mathrm{e}}$ & 12 & 30 & 420 & 530 & 20 & 130 & 1,360 \\
\hline Uranium, unfiltered & $30^{\mathrm{a}}$ & 0 & .151 & .245 & 1.52 & $<.012$ & .118 & 1.80 \\
\hline
\end{tabular}

\section{Bacteria}

Coliform bacteria were detected in samples from six wells (table A9); three of whish were sand and gravel wells and three were bedrock wells. The smallest detection was $1 \mathrm{CFU} / 100 \mathrm{~mL}$ and the greatest was too numerous to count. Any detection of coliform bacteria in finished drinking water is considered to be above the MCL. The owners of these six wells were notified of the results upon receipt from the laboratory. Fecal coliform and E. coli were not detected in any sample. The 
heterotrophic plate count ranged from $<1 \mathrm{CFU} / \mathrm{mL}$ to $940 \mathrm{CFU} / \mathrm{mL}$ with a median of $4 \mathrm{CFU} / \mathrm{mL}$. The USEPA MCL for the heterotrophic plate count is $500 \mathrm{CFU} / \mathrm{mL}$; this limit was exceeded in one sample (940 CFU/mL).

\section{Summary}

Ground-water samples were collected from 13 sand and gravel wells and 14 bedrock wells to characterize the ground-water quality in the Mohawk River Basin. Wells screened in sand and gravel ranged from $22.5 \mathrm{ft}$ to $190 \mathrm{ft}$ deep; the wells completed in bedrock were $75 \mathrm{ft}$ to $815 \mathrm{ft}$ deep and typically tapped shale and sandstone or carbonate rock. Of the 27 wells sampled, 12 were production wells, and 15 were domestic wells. Sample collection and analysis was done through standard USGS procedures and other documented methods. Samples were analyzed for physical properties, major ions, nutrients, trace elements, radon-222, pesticides, VOCs, and bacteria; many constituents were not detected in any sample.

The chemical quality of the samples was generally good, although the concentrations of certain constituents in some samples, including color, $\mathrm{pH}$, sodium, chloride, fluoride, sulfate, aluminum, arsenic, iron, manganese, radon-222 and bacteria exceeded State or Federal drinking water quality standards. Constituents whose concentrations most often exceeded drinking water standards were radon-222 (12 samples with concentrations greater than $300 \mathrm{pCi} / \mathrm{L})$, iron $(10$ samples with concentrations greater than $300 \mu \mathrm{g} / \mathrm{L}$ ), manganese (10 samples with concentrations greater than 50 $\mu \mathrm{g} / \mathrm{L}$ ), and bacteria (6 samples with detections of coliform bacteria). Two samples had arsenic concentrations that exceeded the USEPA MCL of $10 \mu \mathrm{g} / \mathrm{L}$. No pesticide or VOC was detected at a concentration exceeding established drinking water standards. Drinking-water quality standards used for comparison included NYSDOH MCLs and USEPA MCLs, SDWS, and drinking water advisories.

Concentrations and frequencies of some constituents that were detected in samples from sand and gravel wells differed from those in samples from bedrock wells; for example, samples from sand and gravel wells had higher concentrations of dissolved oxygen than samples from bedrock wells. Concentrations of other constituents varied by physiographic region and by underlying bedrock type. Water in the Mohawk River Basin is generally hard to very hard, especially in the Mohawk Valley and areas underlain by carbonate bedrock. Three bedrock wells had elevated levels of sodium and chloride (maximum concentrations $662 \mathrm{mg} / \mathrm{L}$ and 1,070 $\mathrm{mg} / \mathrm{L}$ respectively). Nitrate and nitrite concentrations were generally higher in samples from sand and gravel wells than in those from bedrock wells although no concentrations exceeded established drinking-water standards; conversely, ammonia concentrations were higher in samples from bedrock wells than in samples from sand and gravel wells. Concentrations of several trace elements, including boron, copper, iron, manganese, and strontium were higher in samples from bedrock wells than in those from sand and gravel wells. The highest Radon-222 activities were in samples from bedrock wells (maximum 1,360 pCi/L). Nine pesticides and pesticide degradates were detected in four samples from sand and gravel wells and two samples from bedrock wells; most were degradates of atrazine, alachlor, and metolachlor. Most VOC detections were in samples from sand and gravel wells; these included toluene, tetrachloroethene, and four trihalomethanes, none of which exceeded drinking water standards. 


\section{References Cited}

American Public Health Association, 1998, Standard methods for the examination of water and wastewater (20th ed.): Washington, D.C., American Public Health Association, American Water Works Association, and Water Environment Federation [variously paged].

ASTM International, 2006, D5072-98(2006), Standard test method for radon in drinking water: ASTM International, accessed 12/28/06 at http://www.astm.org.

Butch, G.K., Murray, P.M., Hebert, G.J., and Weigel J.F., 2003, Water Resources Data, New York, Water Year 2002: U.S. Geological Survey Water-Data Report, NY-02-1, p. 502-520.

Childress, C.J.O., Foreman, W.T., Connor, B.F., and Maloney, T.J., 1999, New reporting procedures based on long-term method detection levels and some considerations for interpretations of waterquality data provided by the U.S. Geological Survey National Water Quality Laboratory: U.S. Geological Survey Open-File Report 99-193, 19 p.

Connor, B.F., Rose, D.L., Noriega, M.C., Murtagh, L.K., and Abney, S.R., 1998, Methods of analysis by the U.S. Geological Survey National Water Quality Laboratory-Determination of 86 volatile organic compounds in water by gas chromatography/mass spectrometry, including detections less than reporting limits: U.S. Geological Survey Open-File Report 97-829, 78 p.

Eckhardt, D.A., Reddy, J.E., and Tamulonis, K.L., 2007, Ground-water quality in the Genesee River Basin, New York, 2005-06: U.S. Geological Survey Open-File Report 2007-1093, 26 p. (online only).

Fisher, D.W., Isachsen, Y.W., and Rickard, L.V., 1970, Geologic Map of New York State: New York State Museum - Geological Survey, Map and Chart Series no. 15, Adirondack sheet, scale 1:250,000.

Fishman, M.J., ed., 1993, Methods of analysis by the U.S. Geological Survey National Water Quality Laboratory-Determination of inorganic and organic constituents in water and fluvial sediments: U.S. Geological Survey Open-File Report 93-125, 217 p.

Furlong, E.T., Anderson, B.D., Werner, S.L., Soliven, P.P., Coffey, L.J., and Burkhardt, M.R., 2001, Methods of analysis by the U.S. Geological Survey National Water Quality LaboratoryDetermination of pesticides in water by graphitized carbon-based solid-phase extraction and highperformance liquid chromatography/mass spectrometry: U.S. Geological Survey Water-Resources Investigations Report 01-4134, 73 p.

Garbarino, J.R. and Damrau, D.L., 2001, Methods of analysis by the U.S. Geological Survey National Water Quality Laboratory-Determination of organic plus inorganic mercury in filtered and unfiltered natural water with cold vapor-atomic fluorescence spectrometry: U.S. Geological Survey WaterResources Investigations Report 01-4132, 16 p.

Garbarino, J.R., Kanagy, L.K., and Cree, M.E., 2006, Determination of elements in natural-water, biota, sediment and soil samples using collision/reaction cell inductively coupled plasma-mass spectrometry: U.S. Geological Survey Techniques and Methods, book 5, chap.1, sec. B, 88 p. 
Garbarino, J.R. and Struzeski, T.M., 1998, Methods of analysis by the U.S. Geological Survey National Water Quality Laboratory-Determination of elements in whole-water digests using inductively coupled plasma-optical emission spectrometry and inductively coupled plasma-mass spectrometry: U.S. Geological Survey Open-File Report 98-165, 101 p.

Hammond, D.S., Heath, R.C., and Waller, R.M., 1978, Ground-water data on the Hudson River Basin, New York: U. S. Geological Survey Open File Report 78-710, 18 p.

Hem, J.D., 1985, Study and interpretation of the chemical characteristics of natural water: U.S. Geological Survey Water-Supply Paper 2254, 264 p.

Hetcher-Aguila, K.K., 2005, Ground-water quality in the Chemung River Basin, New York, 2003: U.S. Geological Survey Open-File Report 2004-1329, 19 p. (online only).

Hetcher-Aguila, K.K. and Eckhardt, D.A., 2006, Ground-water quality in the upper Susquehanna River Basin, New York, 2004: U.S. Geological Survey Open-File Report 2006-1161, 21 p. (online only).

Hoffman, G.L., Fishman, M.J., and Garbarino, J.R., 1996, Methods of analysis by the U.S. Geological Survey National Water Quality Laboratory-In-bottle acid digestion of whole-water samples: U.S. Geological Survey Open-File Report 96-225, 28 p.

Isachsen, Y.W., Landing, Ed, Lauber, J.M., Rickard, L.V., and Rogers, W.B., eds., 2000, Geology of New York-A simplified account (2nd ed.): Albany, NY, New York State Museum/Geological Survey, 294 p.

Lee, E.A. and Strahan, A.P., 2003, Methods of analysis by the U.S. Geological Survey Organic Geochemistry Research Group-Determination of acetamide herbicides and their degradations products in water using online solid-phase extraction and liquid chromatography/mass spectrometry: U.S. Geological Survey Open-File Report 03-173, 17 p.

New York State Department of Health, 2007, NYCRR Title 10, Chapter 1, Part 5, Subpart 5-1 Public Water Systems: Tables: Albany, NY, accessed 12/31/07 at http://www.health.state.ny.us/environmental/water/drinking/part5/tables.htm.

Nystrom, E.A., 2006, Ground-water quality in the Lake Champlain Basin, New York, 2004: U.S. Geological Survey Open-File Report 2006-1088, 22 p. (online only).

Nystrom, E.A., 2007a, Ground-water quality in the St. Lawrence River Basin, New York, 2005-06: U.S. Geological Survey Open-File Report 2007-1066, 33 p. (online only).

Nystrom, E.A., 2007b, Ground-water quality in the Delaware River Basin, New York, 2001 \& 2005-06: U.S. Geological Survey Open-File Report 2007-1098, 36 p. (online only).

Patton, C.J. and Truitt, E.P., 2000, Methods of analysis by the U.S. Geological Survey National Water Quality Laboratory-Determination of ammonium plus organic nitrogen by a Kjeldahl digestion method and an automated photometric finish that includes digest cleanup by gas diffusion: U.S. Geological Survey Open-File Report 00-170, 31 p. 
Phillips, P.J. and Hanchar, D.W., 1996, Water-quality assessment of the Hudson River Basin in New York and adjacent States-Analysis of available nutrient, pesticide, volatile organic compound, and suspended-sediment data, 1970-90: U.S. Geological Survey Water-Resources Investigations Report 96-4065, 77 p.

Randall, A.D., 1996, Mean annual runoff, precipitation, and evapotranspiration in the glaciated northeastern United States, 1951-80: U.S. Geological Survey Open-File Report 96-395, 2pl., $1: 250,000$.

Sandstrom, M.W., Stroppel, M.E., Foreman, W.T., and Schroeder, M.P., 2001, Methods of analysis by the U.S. Geological Survey National Water Quality Laboratory-Determination of moderate-use pesticides and selected degradates in water by $\mathrm{C}-18$ solid-phase extraction and gas chromatography/mass spectrometry: U.S. Geological Survey Water-Resources Investigations Report 01-4098, 70 p.

Struzeski, T.M., DeGiacomo, W.J., and Zayhowski, E.J., 1996, Methods of analysis by the U.S. Geological Survey National Water Quality Laboratory-Determination of dissolved aluminum and boron in water by inductively coupled plasma-atomic emission spectrometry: U.S. Geological Survey Open-File Report 96-149, 17 p.

U.S. Environmental Protection Agency, 1983, Methods for chemical analysis of water and wastes: Washington, D.C., U.S. Environmental Protection Agency, Environmental Monitoring and Support Laboratory Office of Research and Development, EPA 600/4-79-020 p. 420.2-1-5.

U.S. Environmental Protection Agency, 1997, Guidelines for preparation of the comprehensive state water quality assessments (305(b) Reports) and electronic updates: Washington, D.C., U.S. Environmental Protection Agency, Office of Water, EPA 841-B-97-002A and EPA 841-B-97-002B, PL95-217, $271 \mathrm{p}$.

U.S. Environmental Protection Agency, 1999, Proposed radon in drinking water rule: Washington, D.C., U.S. Environmental Protection Agency, Office of Water, EPA 815-F-99-006, 6 p.

U.S. Environmental Protection Agency, 2003, National primary drinking water standards and national secondary drinking water standards: Washington, D.C., U.S. Environmental Protection Agency, Office of Water, EPA 816-F-03-016, 6 p.

U.S. Environmental Protection Agency, 2004, Test Methods for Evaluating Solid Waste, Physical/Chemical Methods: EPA SW-846, p. 9060A1--5.

U.S. Geological Survey, variously dated, National field manual for the collection of water-quality data: U.S. Geological Survey Techniques of Water-Resources Investigations, book 9, chaps. A1-A9, [variously paged].

Vogelmann, J.E., Howard, S.M., Yang, L., Larson, C.R., Wylie, B.K., and Van Driel, J.N., 2001, Completion of the 1990's National Land Cover Data Set for the conterminous United States, Photogrammetric Engineering and Remote Sensing v. 67, p. 650-662. 
Wilde, F.D., Radtke, D.B., Gibs, Jacob, and Iwatsubo, R.T., eds., 2004, Processing of water samples (version 2.1): U.S. Geological Survey Techniques of Water-Resources Investigations, book 9, chap. A5, accessed 1/11/07 at http://pubs.water.usgs.gov/twri9A5/

Zaugg, S.D., Sandstrom, M.W., Smith, S.G., and Fehlberg, K.M., 1995, Methods of analysis by the U.S. Geological Survey National Water Quality Laboratory-Determination of pesticides in water by C-18 solid-phase extraction and capillary-column gas chromatography/mass spectrometry with selected-ion monitoring: U.S. Geological Survey Open-File Report 95-181, 60 p. 


\section{Appendix.}

Table A1. Information on wells sampled in the Mohawk River Basin, 2006.

[-- , unknown; Pr, production; Dom, domestic; MHV, Mohawk-Hudson Valley, AKU, Adirondack upland; APU,

Appalachian upland; D, developed; F, forested; A, agricultural; W, wetlands and open water; SS, sandstone]

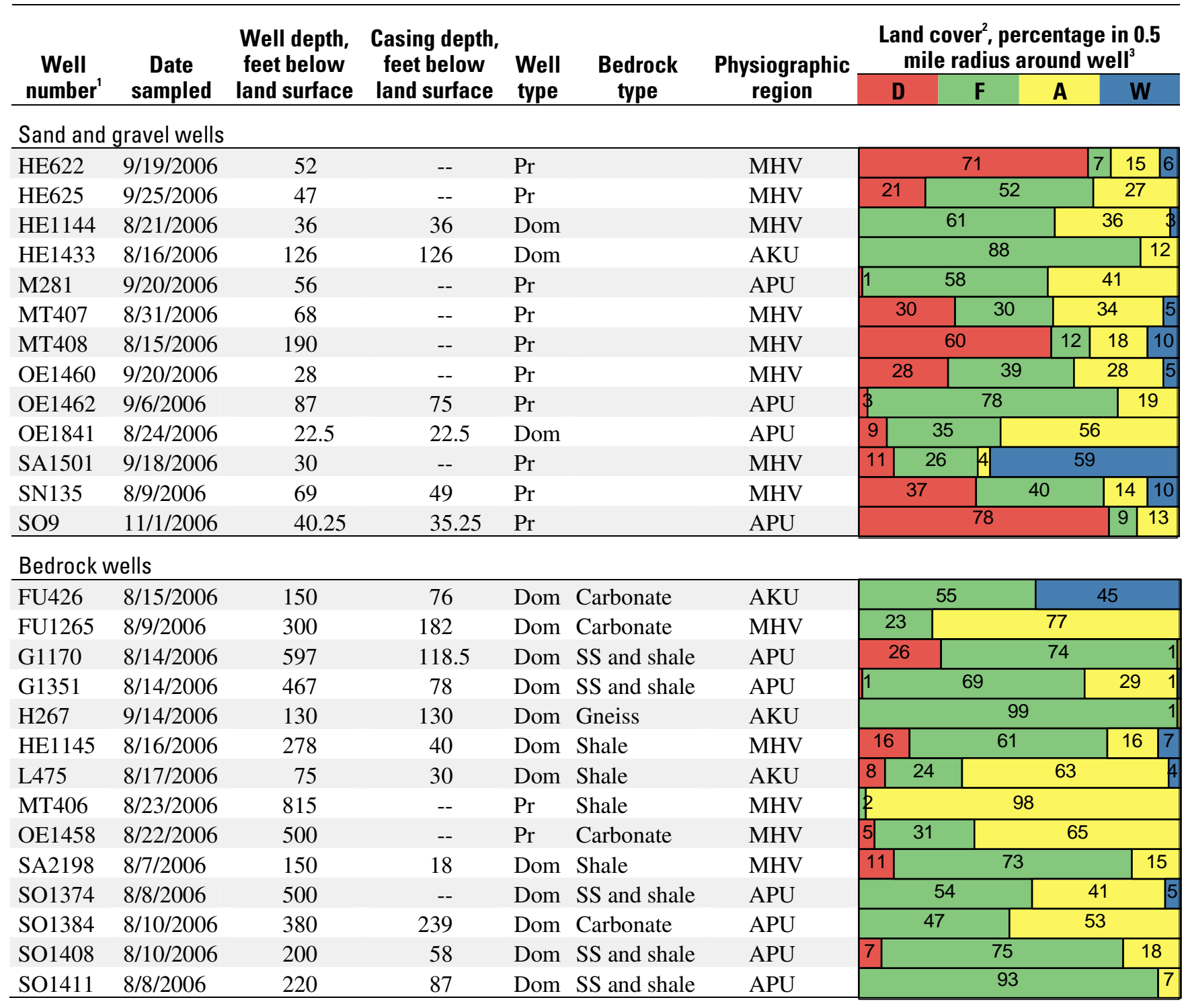

${ }^{1}$ FU, Fulton County; G, Green County; H, Hamilton County; HE, Herkimer County; L, Lewis County; M, Madison County; MT, Montgomery County; OE, Oneida County; SA, Saratoga County; SN, Schenectady County; SO, Schoharie County.

${ }^{2}$ Land cover estimated from the National Land Cover Data set (1992).

${ }^{3}$ Totals may not equal 100 percent as a result of rounding. 
Table A2. Constituents analyzed for but not detected in ground-water samples from the Mohawk River Basin, 2006.

\begin{tabular}{|c|c|c|}
\hline $\begin{array}{c}\text { USGS } \\
\text { parameter } \\
\text { code } \\
\end{array}$ & Compound & $\begin{array}{c}\text { Laboratory } \\
\text { reporting } \\
\text { level }\end{array}$ \\
\hline \multicolumn{3}{|c|}{ Trace Elements in unfiltered water, micrograms per liter } \\
\hline 71900 & Mercury & 0.01 \\
\hline 01077 & Silver & .16 \\
\hline 01059 & Thallium & .2 \\
\hline \multicolumn{3}{|c|}{ Pesticides in filtered water, micrograms per liter } \\
\hline 50470 & 2,4-D methyl ester & .190 \\
\hline 39732 & $2,4-\mathrm{D}$ & .04 \\
\hline 38746 & 2,4-DB & .02 \\
\hline 82660 & 2,6-Diethylaniline & .006 \\
\hline 04038 & $\begin{array}{l}\text { 2-Chloro-6-ethylamino-4- } \\
\text { amino-s-triazine }\end{array}$ & .08 \\
\hline 63781 & $\begin{array}{l}\text { 2-Chloro- } N \text {-(2,6- } \\
\text { diethylphenyl)acetamide }\end{array}$ & .02 \\
\hline 63782 & $\begin{array}{l}\text { 2-Chloro- } N \text {-(2-ethyl-6- } \\
\text { methylphenyl)acetamide }\end{array}$ & .02 \\
\hline 49308 & 3-Hydroxy carbofuran & .008 \\
\hline 61029 & $\begin{array}{l}\text { Acetochlor ethanesulfonic } \\
\text { acid }\end{array}$ & .02 \\
\hline 61030 & Acetochlor oxanilic acid & .02 \\
\hline 62847 & Acetochlor sulfynilacetic acid & .02 \\
\hline 49260 & Acetochlor & .006 \\
\hline 49315 & Acifluorfen & .028 \\
\hline 50009 & Alachlor ethanesulfonic acid & .02 \\
\hline 61031 & Alachlor oxanilic acid & .02 \\
\hline 62848 & Alachlor sulfynilacetic acid & .02 \\
\hline 46342 & Alachlor & .005 \\
\hline 49313 & Aldicarb sulfone & .02 \\
\hline 49314 & Aldicarb sulfoxide & .100 \\
\hline 49312 & Aldicarb & .15 \\
\hline 34253 & alpha-HCH & .005 \\
\hline 82686 & Azinphos-methyl & .050 \\
\hline 50299 & Bendiocarb & .08 \\
\hline 82673 & Benfluralin & .010 \\
\hline 50300 & Benomyl & .022 \\
\hline 61693 & Bensulfuron & .02 \\
\hline 38711 & Bentazon & .02 \\
\hline 04029 & Bromacil & .02 \\
\hline 49311 & Bromoxynil & .04 \\
\hline 04028 & Butylate & .004 \\
\hline 50305 & Caffeine & .018 \\
\hline 49310 & Carbaryl & .02 \\
\hline 82680 & Carbaryl & .041 \\
\hline 49309 & Carbofuran & .016 \\
\hline
\end{tabular}

\begin{tabular}{|c|c|c|}
\hline $\begin{array}{c}\text { USGS } \\
\text { parameter } \\
\text { code }\end{array}$ & Compound & $\begin{array}{c}\text { Laboratory } \\
\text { reporting } \\
\text { level }\end{array}$ \\
\hline \multicolumn{3}{|c|}{ Pesticides in filtered water, micrograms per liter--Continued } \\
\hline 82674 & Carbofuran & .020 \\
\hline 61188 & Chloramben methyl ester & .02 \\
\hline 50306 & Chlorimuron & .032 \\
\hline 04039 & Chlorodiamino-s-triazine & .04 \\
\hline 38933 & Chlorpyrifos & .005 \\
\hline 82687 & cis-Permethrin & .006 \\
\hline 49305 & Clopyralid & .07 \\
\hline 04041 & Cyanazine & .018 \\
\hline 04031 & Cycloate & .01 \\
\hline 49304 & Dacthal monoacid & .03 \\
\hline 82682 & DCPA & .003 \\
\hline 63778 & Dechloroacetochlor & .02 \\
\hline 63777 & Dechloroalachlor & .02 \\
\hline 63779 & Dechlorodimethenamid & .02 \\
\hline 63780 & Dechlorometolachlor & .02 \\
\hline 62170 & Desulfinyl fipronil & .012 \\
\hline 39572 & Diazinon & .005 \\
\hline 38442 & Dicamba & .04 \\
\hline 49302 & Dichlorprop & .03 \\
\hline 39381 & Dieldrin & .009 \\
\hline 61951 & $\begin{array}{l}\text { Dimethenamid ethanesulfonic } \\
\text { acid }\end{array}$ & .02 \\
\hline 62482 & Dimethenamid oxanilic acid & .02 \\
\hline 61588 & Dimethenamid & .02 \\
\hline 49301 & Dinoseb & .04 \\
\hline 04033 & Diphenamid & .01 \\
\hline 82677 & Disulfoton & .02 \\
\hline 49300 & Diuron & .02 \\
\hline 82668 & EPTC & .004 \\
\hline 82663 & Ethalfluralin & .009 \\
\hline 82672 & Ethoprop & .012 \\
\hline 49297 & Fenuron & .10 \\
\hline 62169 & Desulfinylfipronil amide & .029 \\
\hline 62167 & Fipronil sulfide & .013 \\
\hline 62168 & Fipronil sulfone & .024 \\
\hline 62166 & Fipronil & .016 \\
\hline 61952 & Flufenacet ethanesulfonic acid & .02 \\
\hline 62483 & Flufenacet oxanilic acid & .02 \\
\hline 62481 & Flufenacet & .02 \\
\hline 61694 & Flumetsulam & .04 \\
\hline 38811 & Fluometuron & .02 \\
\hline
\end{tabular}




\begin{tabular}{|c|c|c|}
\hline $\begin{array}{c}\text { USGS } \\
\text { parameter } \\
\text { code }\end{array}$ & Compound & $\begin{array}{c}\text { Laboratory } \\
\text { reporting } \\
\text { level }\end{array}$ \\
\hline \multicolumn{3}{|c|}{ Pesticides in filtered water, micrograms per liter--Continued } \\
\hline 04095 & Fonofos & .005 \\
\hline 63784 & Hydroxyacetochlor & .02 \\
\hline 63783 & Hydroxyalachlor & .02 \\
\hline 64045 & Hydroxydimethenamid & .02 \\
\hline 63785 & Hydroxymetolachlor & .02 \\
\hline 50356 & Imazaquin & .04 \\
\hline 50407 & Imazethapyr & .04 \\
\hline 61695 & Imidacloprid & .020 \\
\hline 39341 & Lindane & .004 \\
\hline 38478 & Linuron & .01 \\
\hline 82666 & Linuron & .035 \\
\hline 39532 & Malathion & .027 \\
\hline 38482 & MCPA & .07 \\
\hline 38487 & MCPB & .10 \\
\hline 50359 & Metalaxyl & .03 \\
\hline 38501 & Methiocarb & .034 \\
\hline 49296 & Methomyl & .070 \\
\hline 82667 & Methyl parathion & .015 \\
\hline 82630 & Metribuzin & .028 \\
\hline 61697 & Metsulfuron & .07 \\
\hline 82671 & Molinate & .003 \\
\hline 61692 & $\begin{array}{l}N \text {-(4-Chlorophenyl)- } N \text { - } \\
\text { methylurea }\end{array}$ & .04 \\
\hline 82684 & Napropamide & .007 \\
\hline 49294 & Neburon & .01 \\
\hline 50364 & Nicosulfuron & .04 \\
\hline 49293 & Norflurazon & .02 \\
\hline 49292 & Oryzalin & .02 \\
\hline 38866 & Oxamyl & .05 \\
\hline 34653 & $p, p^{\prime}-\mathrm{DDE}$ & .003 \\
\hline 39542 & Parathion & .010 \\
\hline 82669 & Pebulate & .004 \\
\hline 82683 & Pendimethalin & .022 \\
\hline 82664 & Phorate & .055 \\
\hline 49291 & Picloram & .03 \\
\hline 82676 & Propyzamide & .004 \\
\hline 62766 & Propachlor ethanesulfonic acid & .05 \\
\hline 62767 & Propachlor oxanilic acid & .02 \\
\hline 04024 & Propachlor & .010 \\
\hline 82679 & Propanil & .011 \\
\hline 82685 & Propargite & .02 \\
\hline 49236 & Propham & .030 \\
\hline 50471 & Propiconazole & .01 \\
\hline
\end{tabular}

\begin{tabular}{|c|c|c|}
\hline $\begin{array}{l}\text { USGS } \\
\text { parameter } \\
\text { code }\end{array}$ & Compound & $\begin{array}{c}\text { Laboratory } \\
\text { reporting } \\
\text { level }\end{array}$ \\
\hline \multicolumn{3}{|c|}{ Pesticides in filtered water, micrograms per liter--Continued } \\
\hline 38538 & Propoxur & .008 \\
\hline 38548 & Siduron & .02 \\
\hline 04035 & Simazine & .005 \\
\hline 50337 & Sulfometuron & .090 \\
\hline 82670 & Tebuthiuron & .02 \\
\hline 82665 & Terbacil & .034 \\
\hline 04032 & Terbacil & .026 \\
\hline 82675 & Terbufos & .02 \\
\hline 82681 & Thiobencarb & .010 \\
\hline 82678 & Triallate & .006 \\
\hline 49235 & Triclopyr & .03 \\
\hline 82661 & Trifluralin & .009 \\
\hline \multicolumn{3}{|c|}{$\begin{array}{l}\text { Volatile organic compounds in unfiltered water, } \\
\text { micrograms per liter }\end{array}$} \\
\hline 34506 & 1,1,1-Trichloroethane & .1 \\
\hline 77652 & $\begin{array}{l}\text { 1,1,2-Trichloro-1,2,2- } \\
\text { trifluoroethane }\end{array}$ & .1 \\
\hline 34496 & 1,1-Dichloroethane & .1 \\
\hline 34501 & 1,1-Dichloroethene & .1 \\
\hline 34536 & 1,2-Dichlorobenzene & .1 \\
\hline 32103 & 1,2-Dichloroethane & .2 \\
\hline 34541 & 1,2-Dichloropropane & .1 \\
\hline 34566 & 1,3-Dichlorobenzene & .1 \\
\hline 34571 & 1,4-Dichlorobenzene & .1 \\
\hline 34030 & Benzene & .1 \\
\hline 34301 & Chlorobenzene & .1 \\
\hline 77093 & cis-1,2-Dichloroethene & .1 \\
\hline 34668 & Dichlorodifluoromethane & .2 \\
\hline 34423 & Dichloromethane & .2 \\
\hline 81576 & Diethyl ether & .2 \\
\hline 81577 & Diisopropyl ether & .2 \\
\hline 34371 & Ethylbenzene & .1 \\
\hline 50005 & Methyl tert-pentyl ether & .2 \\
\hline 85795 & $m$-Xylene plus $p$-xylene & .2 \\
\hline 77135 & $o$-Xylene & .1 \\
\hline 77128 & Styrene & .1 \\
\hline 50004 & tert-Butyl ethyl ether & .1 \\
\hline 78032 & Methyl tert-butyl ether & .2 \\
\hline 32102 & Tetrachloromethane & .2 \\
\hline 34546 & trans-1,2-Dichloroethene & .1 \\
\hline 39180 & Trichloroethene & .1 \\
\hline 34488 & Trichlorofluoromethane & .2 \\
\hline 39175 & Vinyl chloride & .2 \\
\hline
\end{tabular}


Table A3. Physical properties of ground-water samples from the Mohawk River Basin, 2006.

[mg/L, milligrams per liter; $\mu \mathrm{S} / \mathrm{cm} @ 25^{\circ} \mathrm{C}$, microsiemens per centimeter at 25 degrees Celsius; (00080), USGS National Water Information System parameter code; <, less than; bold values exceed one or more drinking water standards]

\begin{tabular}{|c|c|c|c|c|c|}
\hline $\begin{array}{c}\text { Well } \\
\text { number' }^{1}\end{array}$ & $\begin{array}{c}\text { Color, } \\
\text { platinum- } \\
\text { cobalt units } \\
(00080)\end{array}$ & $\begin{array}{c}\text { Dissolved } \\
\text { oxygen, } \\
\text { mg/L } \\
(00300) \\
\end{array}$ & $\begin{array}{c}\text { pH, } \\
\text { standard } \\
\text { units } \\
(00400) \\
\end{array}$ & $\begin{array}{c}\text { Specific } \\
\text { conductance, } \\
\mu \mathrm{S} / \mathrm{cm} @ \\
25^{\circ} \mathrm{C} \\
(00095) \\
\end{array}$ & $\begin{array}{c}\text { Water } \\
\text { temperature, } \\
\text { degrees } \\
\text { Celsius } \\
(00010) \\
\end{array}$ \\
\hline \multicolumn{6}{|c|}{ Sand and gravel wells } \\
\hline HE622 & 2 & 7.9 & 7.2 & 1,040 & 9.9 \\
\hline HE625 & 2 & 6.9 & 7.4 & 366 & 10.1 \\
\hline HE1144 & 2 & 9.1 & 7.6 & 283 & 10.1 \\
\hline HE1433 & 2 & 8.6 & 8.1 & 106 & 9.5 \\
\hline M281 & $<1$ & .3 & 7.2 & 547 & 8.9 \\
\hline MT407 & 8 & 5.9 & 7.2 & 519 & 9.8 \\
\hline MT408 & 5 & .1 & 7.1 & 1,020 & 11.2 \\
\hline OE1460 & 2 & 5.6 & 7.1 & 910 & 13.6 \\
\hline OE1462 & 10 & .3 & 7.3 & 749 & 9.6 \\
\hline OE1841 & 15 & .1 & 7.3 & 768 & 12.3 \\
\hline SA1501 & 2 & .6 & 7.1 & 455 & 12.4 \\
\hline SN135 & 2 & 12.2 & 7.4 & 443 & 12.4 \\
\hline SO9 & 8 & .5 & 6.1 & 1,100 & 12.2 \\
\hline \multicolumn{6}{|c|}{ Bedrock wells } \\
\hline FU426 & 20 & 2.4 & 7.9 & 32 & 9.8 \\
\hline FU1265 & 5 & .1 & 7.7 & 315 & 11.1 \\
\hline G1170 & $<1$ & .6 & 8.2 & 1,940 & 11.8 \\
\hline G1351 & 2 & .2 & 8.7 & 2,230 & 11.5 \\
\hline H267 & 2 & .2 & 8.1 & 84 & 8.5 \\
\hline HE1145 & 2 & $<.1$ & 8.2 & 714 & 12.3 \\
\hline L475 & 8 & .1 & 7.9 & 685 & 10.9 \\
\hline MT406 & 5 & 5.6 & 6.6 & 1,060 & 9.4 \\
\hline OE1458 & 2 & .4 & 6.9 & 466 & 9.6 \\
\hline SA2198 & 2 & 7.8 & 7.1 & 475 & 12.2 \\
\hline SO1374 & 5 & .1 & 7.1 & 800 & 14.5 \\
\hline SO1384 & $<1$ & 4.5 & 7.0 & 1,170 & 11.0 \\
\hline SO1408 & $<1$ & .1 & 7.3 & 171 & 11.1 \\
\hline SO1411 & 2 & .1 & 7.7 & 670 & 10.9 \\
\hline
\end{tabular}

${ }^{1}$ FU, Fulton County; G, Green County; H, Hamilton County; HE, Herkimer County; L, Lewis County; M, Madison County; MT, Montgomery County; OE, Oneida County; SA, Saratoga County; SN, Schenectady County; SO, Schoharie County. 
Table A4. Concentrations of major ions in ground-water samples from the Mohawk River Basin, 2006.

[mg/L, milligrams per liter; $\mathrm{CaCO}_{3}$, calcium carbonate; (00900), USGS National Water Information System parameter code; $<$, less than; E, estimated value; bold values exceed one or more drinking water standards]

\begin{tabular}{|c|c|c|c|c|c|c|c|}
\hline $\begin{array}{c}\text { Well } \\
\text { number' }\end{array}$ & $\begin{array}{c}\text { Hardness, } \\
\text { filtered, } \\
\mathrm{mg} / \mathrm{L} \text { as } \\
\mathrm{CaCO}_{3} \\
(00900) \\
\end{array}$ & $\begin{array}{c}\text { Calcium, } \\
\text { filtered, } \\
\text { mg/L } \\
(00915)\end{array}$ & $\begin{array}{c}\text { Magnesium, } \\
\text { filtered, } \\
\text { mg/L } \\
(00925) \\
\end{array}$ & $\begin{array}{c}\text { Potassium, } \\
\text { filtered, } \\
\text { mg/L } \\
(00935) \\
\end{array}$ & $\begin{array}{c}\text { Sodium, } \\
\text { filtered, } \\
\text { mg/L } \\
(00930)\end{array}$ & $\begin{array}{c}\text { Acid neutralizing } \\
\text { capacity, } \\
\text { unfiltered, } \\
\text { mg/L as CaCO } \\
(90410)\end{array}$ & $\begin{array}{c}\text { Alkalinity, } \\
\text { filtered, } \\
\text { fixed end point, lab, } \\
\text { mg/L as } \mathrm{CaCO}_{3} \\
\text { (29801) }\end{array}$ \\
\hline \multicolumn{8}{|c|}{ Sand and gravel wells } \\
\hline HE622 & 310 & 97.8 & 17.0 & 3.60 & 68.2 & 242 & 243 \\
\hline HE625 & 190 & 58.3 & 10.2 & 1.07 & 4.06 & 184 & 184 \\
\hline HE1144 & 140 & 44.5 & 7.81 & .50 & 2.58 & 130 & 130 \\
\hline HE1433 & 47 & 15.8 & 1.95 & .53 & 1.48 & 45 & 45 \\
\hline M281 & 300 & 63.5 & 35.3 & 1.29 & 3.89 & 276 & 278 \\
\hline MT407 & 250 & 63.9 & 23.2 & 1.09 & 11.8 & 224 & 236 \\
\hline MT408 & 340 & 87.7 & 29.0 & 2.84 & 73.6 & 284 & 283 \\
\hline OE1460 & 350 & 91.5 & 29.3 & 2.09 & 55.1 & 294 & 290 \\
\hline OE1462 & 330 & 86.3 & 28.4 & 1.18 & 24.7 & 199 & 198 \\
\hline OE1841 & 380 & 58.9 & 57.0 & 2.33 & 13.2 & 322 & 323 \\
\hline SA1501 & 230 & 72.6 & 11.2 & 2.38 & 15.2 & 210 & 212 \\
\hline SN135 & 180 & 54.8 & 9.33 & 1.22 & 19.6 & 169 & 170 \\
\hline SO9 & 400 & 132 & 16.2 & 3.99 & 70.4 & 289 & 288 \\
\hline \multicolumn{8}{|c|}{ Bedrock wells } \\
\hline FU426 & 34 & 9.70 & 2.39 & .89 & 4.12 & 34 & 34 \\
\hline FU1265 & 120 & 30.6 & 10.5 & .70 & 23.4 & 161 & 160 \\
\hline G1170 & 81 & 26.6 & 3.67 & .87 & 662 & 108 & 108 \\
\hline G1351 & 23 & 7.31 & 1.08 & 1.27 & 411 & 122 & 120 \\
\hline H267 & 34 & 9.21 & 2.76 & .56 & 6.08 & 48 & 47 \\
\hline HE1145 & 34 & 5.87 & 4.67 & 2.92 & 139 & 331 & 331 \\
\hline L475 & 51 & 13.6 & 4.01 & 7.38 & 112 & 165 & 166 \\
\hline MT406 & 420 & 123 & 28.5 & 4.24 & 51.4 & 295 & 293 \\
\hline OE1458 & 240 & 72.1 & 15.7 & 1.78 & 5.82 & 226 & 226 \\
\hline SA2198 & 360 & 106 & 23.8 & 2.29 & 80.6 & 386 & 318 \\
\hline SO1374 & 510 & 115 & 53.7 & 3.73 & 139 & 369 & 367 \\
\hline SO1384 & 280 & 67.3 & 28.3 & 2.17 & 86.6 & 240 & 240 \\
\hline SO1408 & 89 & 23.0 & 7.61 & .70 & 41.9 & 176 & 176 \\
\hline SO1411 & 71 & 21.4 & 4.15 & .84 & 247 & 309 & 309 \\
\hline
\end{tabular}

${ }^{1}$ FU, Fulton County; G, Green County; H, Hamilton County; HE, Herkimer County; L, Lewis County; M, Madison County; MT, Montgomery County; OE, Oneida County; SA, Saratoga County; SN, Schenectady County; SO, Schoharie County. 
Table A4. Concentrations of major ions in ground-water samples from the Mohawk River Basin, 2006.Continued

[mg/L, milligrams per liter; $\mathrm{CaCO}_{3}$, calcium carbonate; (00900), USGS National Water Information System parameter code; $<$, less than; E, estimated value; bold values exceed one or more drinking water standards]

\begin{tabular}{|c|c|c|c|c|c|c|}
\hline $\begin{array}{c}\text { Well } \\
\text { number }\end{array}$ & $\begin{array}{c}\text { Bicarbonate }{ }^{2}, \\
\text { filtered, } \\
\text { fixed end } \\
\text { point, lab, } \\
\text { mg/L } \\
(29805) \\
\end{array}$ & $\begin{array}{c}\text { Chloride, } \\
\text { filtered, } \\
\text { mg/L } \\
(00940) \\
\end{array}$ & $\begin{array}{c}\text { Fluoride, } \\
\text { filtered, } \\
\text { mg/L } \\
(00950) \\
\end{array}$ & $\begin{array}{c}\text { Silica, } \\
\text { filtered, } \\
\text { mg/L } \\
(00955)\end{array}$ & $\begin{array}{c}\text { Sulfate, } \\
\text { filtered, } \\
\text { mg/L } \\
(00945)\end{array}$ & $\begin{array}{c}\text { Residue on } \\
\text { evaporation, } \\
\text { filtered, } \\
\mathrm{mg} / \mathrm{L} \\
(70300) \\
\end{array}$ \\
\hline \multicolumn{7}{|c|}{ Sand and gravel wells } \\
\hline HE622 & 296 & 130 & $<0.1$ & 7.22 & 35.3 & 531 \\
\hline HE625 & 224 & 5.23 & E.1 & 8.03 & 8.7 & 201 \\
\hline HE1144 & 159 & 4.19 & E.1 & 10.1 & 10.9 & 167 \\
\hline HE1433 & 55 & 1.85 & .1 & 13.2 & 4.4 & 72 \\
\hline M281 & 339 & 4.46 & .1 & 8.23 & 37.1 & 334 \\
\hline MT407 & 288 & 21.7 & E.1 & 8.19 & 18.7 & 303 \\
\hline MT408 & 345 & 150 & .5 & 15.3 & 21.5 & 552 \\
\hline OE1460 & 354 & 98.1 & E.1 & 6.21 & 30.4 & 453 \\
\hline OE1462 & 242 & 65.7 & .1 & 13.2 & 99.5 & 463 \\
\hline OE1841 & 394 & 35.0 & E.1 & 11.6 & 54.2 & 433 \\
\hline SA1501 & 259 & 21.9 & .2 & 11.8 & 19.5 & 283 \\
\hline SN135 & 207 & 27.3 & E.1 & 6.67 & 18.4 & 252 \\
\hline SO9 & 351 & 141 & .1 & 10.8 & 60.8 & 627 \\
\hline \multicolumn{7}{|c|}{ Bedrock wells } \\
\hline FU426 & 41 & .50 & E.1 & 15.4 & 7.7 & 57 \\
\hline FU1265 & 195 & 2.20 & .5 & 8.88 & 14.3 & 194 \\
\hline G1170 & 132 & 1,070 & .5 & 6.42 & 2.4 & 1,920 \\
\hline G1351 & 146 & 600 & .6 & 6.80 & $<.9$ & 1,130 \\
\hline $\mathrm{H} 267$ & 57 & .31 & .6 & 16.5 & 2.1 & 71 \\
\hline HE1145 & 404 & 20.2 & 2.8 & 7.66 & 12.4 & 409 \\
\hline L475 & 203 & 110 & E.1 & 9.17 & 8.5 & 361 \\
\hline MT406 & 357 & 110 & .3 & 7.15 & 101 & 634 \\
\hline OE1458 & 276 & 6.94 & .1 & 10.9 & 20.5 & 266 \\
\hline SA2198 & 388 & 132 & .3 & 16.2 & 45.7 & 620 \\
\hline SO1374 & 448 & 13.0 & .4 & 11.0 & 451 & 1,070 \\
\hline SO1384 & 293 & 150 & .5 & 10.9 & 80.3 & 609 \\
\hline SO1408 & 215 & 1.00 & .2 & 9.63 & 11.4 & 202 \\
\hline SO1411 & 377 & 235 & .7 & 8.26 & 1.8 & 736 \\
\hline
\end{tabular}

${ }^{1}$ FU, Fulton County; G, Green County; H, Hamilton County; HE, Herkimer County; L, Lewis County; M, Madison County; MT, Montgomery County; OE, Oneida County; SA, Saratoga County; SN, Schenectady County; SO, Schoharie County.

${ }^{2}$ Bicarbonate values calculated from alkalinity. 
Table A5. Concentrations of nutrients and organic carbon in ground-water samples from the Mohawk River Basin, 2006.

[N, nitrogen; P, phosphorus; mg/L, milligrams per liter; (00623), USGS National Water Information System parameter code; $<$, less than; E, estimated value]

\begin{tabular}{|c|c|c|c|c|c|c|}
\hline $\begin{array}{c}\text { Well } \\
\text { number' }\end{array}$ & $\begin{array}{l}\text { Ammonia plus } \\
\text { organic-N, } \\
\text { filtered, } \\
\text { mg/L as } N \\
(00623) \\
\end{array}$ & $\begin{array}{c}\text { Ammonia, } \\
\text { filtered, } \\
\text { mg/L as N } \\
(00608)\end{array}$ & $\begin{array}{c}\text { Nitrate plus } \\
\text { nitrite, } \\
\text { filtered, } \\
\text { mg/L as N } \\
\text { (00631) }\end{array}$ & $\begin{array}{c}\text { Nitrite, } \\
\text { filtered, } \\
\text { mg/L as } N \\
\text { (00613) }\end{array}$ & $\begin{array}{c}\text { Ortho- } \\
\text { phosphate, } \\
\text { filtered, } \\
\text { mg/L as } P \\
\text { (00671) } \\
\end{array}$ & $\begin{array}{c}\text { Organic } \\
\text { carbon, } \\
\text { unfiltered } \\
\mathrm{mg} / \mathrm{L} \\
(00680)\end{array}$ \\
\hline \multicolumn{7}{|c|}{ Sand and gravel wells } \\
\hline HE622 & E 0.08 & $<0.010$ & 2.60 & $<0.002$ & E 0.004 & 1 \\
\hline HE625 & E.06 & E.006 & .43 & $<.002$ & E.005 & $<1$ \\
\hline HE1144 & E.05 & $<.010$ & 1.65 & E.001 & .007 & $<1$ \\
\hline HE1433 & $<.10$ & $<.010$ & .43 & $<.002$ & .013 & $<1$ \\
\hline M281 & $<.10$ & E.010 & .18 & .003 & .006 & 1.3 \\
\hline MT407 & E.06 & E.006 & 1.94 & $<.002$ & E.005 & 1 \\
\hline MT408 & 1.2 & 1.02 & $<.06$ & $<.002$ & .014 & $<1$ \\
\hline OE1460 & $<.10$ & E.006 & 2.04 & $<.002$ & E.004 & 1.1 \\
\hline OE1462 & E. 10 & .075 & $<.06$ & $<.002$ & .007 & $<1$ \\
\hline OE1841 & .17 & .175 & $<.06$ & $<.002$ & .008 & $<1$ \\
\hline SA1501 & .48 & .343 & E.04 & $<.002$ & .007 & 1.6 \\
\hline SN135 & $<.10$ & $<.010$ & .28 & $<.002$ & .143 & 1.1 \\
\hline SO9 & .27 & .227 & $<.06$ & $<.002$ & E.005 & 1.1 \\
\hline \multicolumn{7}{|c|}{ Bedrock wells } \\
\hline FU426 & $<.10$ & E.005 & .15 & $<.002$ & .123 & $<1$ \\
\hline FU1265 & .36 & .377 & $<.06$ & $<.002$ & .084 & $<1$ \\
\hline G1170 & .22 & .213 & $<.06$ & $<.002$ & .019 & $<1$ \\
\hline G1351 & .37 & .351 & $<.06$ & $<.002$ & .065 & $<1$ \\
\hline H267 & $<.10$ & .022 & $<.06$ & $<.002$ & .039 & $<1$ \\
\hline HE1145 & 2.1 & 1.88 & $<.06$ & $<.002$ & .014 & $<1$ \\
\hline L475 & 1.9 & 1.85 & $<.06$ & $<.002$ & .007 & $<1$ \\
\hline MT406 & .47 & .409 & $<.06$ & $<.002$ & .007 & $<1$ \\
\hline OE1458 & .33 & .163 & $<.06$ & $<.002$ & .006 & $<1$ \\
\hline SA2198 & .50 & .479 & E. 03 & $<.002$ & .009 & $<1$ \\
\hline SO1374 & 1.6 & 1.67 & $<.06$ & $<.002$ & .035 & $<1$ \\
\hline SO1384 & E.08 & .036 & .60 & $<.002$ & .016 & $<1$ \\
\hline SO1408 & $<.10$ & .029 & $<.06$ & $<.002$ & .007 & $<1$ \\
\hline SO1411 & .37 & .347 & $<.06$ & $<.002$ & .031 & $<1$ \\
\hline
\end{tabular}

${ }^{1}$ FU, Fulton County; G, Green County; H, Hamilton County; HE, Herkimer County; L, Lewis County; M, Madison County; MT, Montgomery County; OE, Oneida County; SA, Saratoga County; SN, Schenectady County; SO, Schoharie County. 
Table A6. Concentrations of trace elements and radionuclides in ground-water samples from the Mohawk River Basin, 2006.

[ $\mu \mathrm{g} / \mathrm{L}$, micrograms per liter; (01106), USGS National Water Information System parameter code; <, less than; E, estimated value; $\mathrm{M}$, presence verified but not quantified; bold values exceed one or more drinking water standards]

\begin{tabular}{|c|c|c|c|c|c|c|c|c|}
\hline $\begin{array}{c}\text { Well } \\
\text { number' }\end{array}$ & $\begin{array}{c}\text { Aluminum, } \\
\text { unfiltered, } \\
\mu \mathrm{g} / \mathrm{L} \\
(01105) \\
\end{array}$ & $\begin{array}{c}\text { Antimony, } \\
\text { unfiltered, } \\
\mu \mathrm{g} / \mathrm{L} \\
(01097)\end{array}$ & $\begin{array}{c}\text { Arsenic, } \\
\text { unfiltered, } \\
\mu \mathrm{g} / \mathrm{L} \\
(01002) \\
\end{array}$ & $\begin{array}{c}\text { Barium, } \\
\text { unfiltered, } \\
\mu \mathrm{g} / \mathrm{L} \\
(01007)\end{array}$ & $\begin{array}{c}\text { Beryllium, } \\
\text { unfiltered, } \\
\mu \mathrm{g} / \mathrm{L} \\
(01012)\end{array}$ & $\begin{array}{c}\text { Boron, } \\
\text { filtered, } \\
\mu \mathrm{g} / \mathrm{L} \\
(01020)\end{array}$ & $\begin{array}{c}\text { Cadmium, } \\
\text { unfiltered, } \\
\mu \mathrm{g} / \mathrm{L} \\
(01027)\end{array}$ & $\begin{array}{c}\text { Chromium, } \\
\text { unfiltered, } \\
\mu \mathrm{g} / \mathrm{L} \\
(01034) \\
\end{array}$ \\
\hline \multicolumn{9}{|c|}{ Sand and gravel wells } \\
\hline HE622 & $<2$ & $<0.2$ & 0.60 & 200 & $<0.06$ & 27 & E 0.03 & $<0.60$ \\
\hline HE625 & $<2$ & $<.2$ & .15 & 20 & $<.06$ & 9.8 & $<.04$ & E. 50 \\
\hline HE1144 & 18 & $<.2$ & .46 & 3 & $<.06$ & E 6.2 & $<.04$ & .85 \\
\hline HE1433 & 4 & $<.2$ & .12 & M & $<.06$ & E 4.1 & $<.04$ & .88 \\
\hline M281 & E 1 & $<.2$ & .66 & 58 & $<.06$ & 20 & $<.04$ & $<.60$ \\
\hline MT407 & $<2$ & $<.2$ & .20 & 17 & $<.06$ & 11 & $<.04$ & E. .33 \\
\hline MT408 & E 1 & $<.2$ & 1.5 & 916 & $<.06$ & 125 & E. 03 & $<.60$ \\
\hline OE1460 & $<2$ & $<.2$ & .21 & 97 & $<.06$ & 28 & $<.04$ & $<.60$ \\
\hline OE1462 & $<2$ & $<.2$ & 17.8 & 69 & E. 03 & 24 & $<.04$ & $<.60$ \\
\hline OE1841 & E 1 & $<.2$ & 4.0 & 104 & $<.06$ & 43 & $<.04$ & $<.60$ \\
\hline SA1501 & $<2$ & $<.2$ & .38 & 20 & $<.06$ & 24 & .05 & E. 45 \\
\hline SN135 & $<2$ & $<.2$ & .55 & 23 & $<.06$ & 15 & $<.04$ & $<.60$ \\
\hline SO9 & $<2$ & $<.2$ & 1.2 & 100 & $<.06$ & 49 & $<.02$ & $<.60$ \\
\hline \multicolumn{9}{|c|}{ Bedrock wells } \\
\hline FU426 & 348 & $<.2$ & .41 & 8 & E.04 & $<7.0$ & $<.04$ & 14.8 \\
\hline FU1265 & 49 & $<.2$ & 4.8 & 70 & $<.06$ & 35 & $<.04$ & $<.60$ \\
\hline G1170 & 59 & $<.4$ & 16.4 & 475 & $<.12$ & 104 & $<.08$ & E. 30 \\
\hline G1351 & 5 & $<.2$ & 6.5 & 261 & $<.06$ & 264 & E. 03 & $<.60$ \\
\hline H267 & 7 & $<.2$ & Е.09 & 4 & $<.06$ & E 5.8 & $<.04$ & E. .38 \\
\hline HE1145 & 5 & $<.2$ & Е .07 & 118 & $<.06$ & 608 & $<.04$ & E. .57 \\
\hline L475 & $<2$ & $<.2$ & E.06 & 95 & $<.06$ & 76 & $<.04$ & E. 49 \\
\hline MT406 & $<2$ & $<.2$ & .91 & 105 & $<.06$ & 139 & $<.04$ & $<.60$ \\
\hline OE1458 & $<2$ & $<.2$ & E.06 & 178 & $<.06$ & 28 & .19 & E. 36 \\
\hline SA2198 & 23 & $<.2$ & .79 & 171 & $<.06$ & 76 & $<.02$ & $<.60$ \\
\hline SO1374 & 10 & $<.2$ & 9.3 & 56 & $<.06$ & 410 & E.03 & $<.60$ \\
\hline SO1384 & E 2 & .4 & .20 & 51 & $<.06$ & 345 & $<.04$ & E. 56 \\
\hline SO1408 & 4 & $<.2$ & .39 & 56 & $<.06$ & 329 & $<.04$ & E. 31 \\
\hline SO1411 & 12 & $<.2$ & .14 & 147 & $<.06$ & 399 & $<.04$ & $<.60$ \\
\hline
\end{tabular}

${ }^{1}$ FU, Fulton County; G, Green County; H, Hamilton County; HE, Herkimer County; L, Lewis County; M, Madison County; MT, Montgomery County; OE, Oneida County; SA, Saratoga County; SN, Schenectady County; SO, Schoharie County. 
Table A6. Concentrations of trace elements and radionuclides in ground-water samples from the Mohawk River Basin, 2006. - Continued

[ $\mu \mathrm{g} / \mathrm{L}$, micrograms per liter; (01106), USGS National Water Information System parameter code; <, less than; E, estimated value; $\mathrm{M}$, presence verified but not quantified; bold values exceed one or more drinking water standards]

\begin{tabular}{|c|c|c|c|c|c|c|c|c|}
\hline $\begin{array}{c}\text { Well } \\
\text { number' }\end{array}$ & $\begin{array}{c}\text { Cobalt, } \\
\text { unfiltered, } \\
\mu \mathrm{g} / \mathrm{L} \\
(01037)\end{array}$ & $\begin{array}{c}\text { Copper, } \\
\text { unfiltered, } \\
\mu \mathrm{g} / \mathrm{L} \\
(01042)\end{array}$ & $\begin{array}{c}\text { Iron, } \\
\text { filtered, } \\
\mu \mathrm{g} / \mathrm{L} \\
(01046)\end{array}$ & $\begin{array}{c}\text { Iron, } \\
\text { unfiltered, } \\
\mu \mathrm{g} / \mathrm{L} \\
(01045)\end{array}$ & $\begin{array}{c}\text { Lead, } \\
\text { unfiltered, } \\
\mu \mathrm{g} / \mathrm{L} \\
(01051)\end{array}$ & $\begin{array}{c}\text { Lithium, } \\
\text { unfiltered, } \\
\mu \mathrm{g} / \mathrm{L} \\
(\mathbf{0 1 1 3 2})\end{array}$ & $\begin{array}{c}\text { Manganese, } \\
\text { filtered, } \\
\mu \mathrm{g} / \mathrm{L} \\
(01056) \\
\end{array}$ & $\begin{array}{c}\text { Manganese } \\
\text { unfiltered, } \\
\mu \mathrm{g} / \mathrm{L} \\
(01055)\end{array}$ \\
\hline \multicolumn{9}{|c|}{ Sand and gravel wells } \\
\hline HE622 & 0.183 & 3.6 & $<6$ & E 6 & 0.15 & 5.7 & E 0.5 & $<0.6$ \\
\hline HE625 & .114 & .9 & $<6$ & $<6$ & .09 & 1.3 & $<.6$ & $<.6$ \\
\hline HE1144 & .113 & 4.7 & $<6$ & 580 & 2.13 & 1.9 & 1.6 & 18.1 \\
\hline HE1433 & E. .028 & .6 & 8 & 150 & .07 & 1.8 & 2.3 & 3.8 \\
\hline M281 & .270 & 4.2 & 23 & 28 & E. 03 & 12.9 & 10.1 & 10.1 \\
\hline MT407 & .163 & 1.6 & 8 & 29 & .13 & 1.0 & E. 3 & $<.6$ \\
\hline MT408 & .173 & 2.3 & 1,230 & 1,170 & .09 & 75.7 & 160 & 149 \\
\hline OE1460 & .235 & 1.0 & $<6$ & E 3 & E. 06 & 10.4 & $<.6$ & $<.6$ \\
\hline OE1462 & .152 & 1.0 & 251 & 254 & .34 & 10.4 & 33.0 & 31.1 \\
\hline OE1841 & .240 & 1.2 & 1,240 & 1,210 & $<.06$ & 18.1 & 41.8 & 38.4 \\
\hline SA1501 & .742 & 1.2 & E 4 & 7 & .07 & 4.7 & 1,960 & 2,020 \\
\hline SN135 & .150 & 3.2 & E 4 & E 4 & .09 & 2.6 & 111 & 106 \\
\hline SO9 & .418 & E. 8 & 1,140 & 1,180 & $<.06$ & 7.6 & 349 & 390 \\
\hline \multicolumn{9}{|c|}{ Bedrock wells } \\
\hline FU426 & .389 & 26.2 & 81 & 8,190 & .88 & E.5 & .8 & 93.7 \\
\hline FU1265 & .138 & E.5 & 229 & 326 & .25 & .8 & 50.2 & 49.9 \\
\hline G1170 & .090 & 6.0 & 62 & 273 & .46 & 111 & 306 & 306 \\
\hline G1351 & Е.027 & 1.2 & 18 & 52 & Е .03 & 352 & 12.0 & 12.1 \\
\hline H267 & Е.031 & 2.7 & 44 & 66 & .13 & $<.6$ & 23.2 & 22.0 \\
\hline HE1145 & Е.023 & .7 & $<6$ & 19 & $<.06$ & 824 & $<.6$ & E. 5 \\
\hline L475 & Е.033 & 1.5 & 389 & 381 & E. 03 & 106 & 51.1 & 45.8 \\
\hline MT406 & .260 & 3.0 & 154 & 143 & $<.06$ & 14.5 & 19.9 & 18.3 \\
\hline OE1458 & .106 & 3.8 & 88 & 84 & E.03 & 9.1 & 24.0 & 20.0 \\
\hline SA2198 & .556 & 3.3 & $<6$ & 980 & 2.21 & 28.0 & 220 & 279 \\
\hline SO1374 & .378 & 9.7 & 2,190 & 2,150 & .54 & 115 & 253 & 277 \\
\hline SO1384 & .247 & 7.6 & 9 & 17 & .13 & 38.7 & 5.3 & 5.3 \\
\hline SO1408 & .109 & E.6 & 39 & 49 & .10 & 48.7 & 148 & 144 \\
\hline SO1411 & .060 & 1.6 & 419 & 505 & .12 & 608 & 97.6 & 97.5 \\
\hline
\end{tabular}

${ }^{1}$ FU, Fulton County; G, Green County; H, Hamilton County; HE, Herkimer County; L, Lewis County; M, Madison County; MT, Montgomery County; OE, Oneida County; SA, Saratoga County; SN, Schenectady County; SO, Schoharie County. 
Table A6. Concentrations of trace elements and radionuclides in ground-water samples from the Mohawk River Basin, 2006. - Continued

[ $\mu \mathrm{g} / \mathrm{L}$, micrograms per liter; (01106), USGS National Water Information System parameter code; <, less than; E, estimated value; $\mathrm{M}$, presence verified but not quantified; bold values exceed one or more drinking water standards]

\begin{tabular}{|c|c|c|c|c|c|c|c|}
\hline $\begin{array}{c}\text { Well } \\
\text { number }^{1}\end{array}$ & $\begin{array}{c}\text { Molybdenum, } \\
\text { unfiltered, } \\
\mu \mathrm{g} / \mathrm{L} \\
(01062)\end{array}$ & $\begin{array}{c}\text { Nickel, } \\
\text { unfiltered, } \\
\mu \mathrm{g} / \mathrm{L} \\
(01067)\end{array}$ & $\begin{array}{c}\text { Selenium, } \\
\text { unfiltered, } \\
\mu \mathrm{g} / \mathrm{L} \\
(01147)\end{array}$ & $\begin{array}{c}\text { Strontium, } \\
\text { unfiltered, } \\
\mu \mathrm{g} / \mathrm{L} \\
(\mathbf{0 1 0 8 2})\end{array}$ & $\begin{array}{c}\text { Zinc, } \\
\text { unfiltered, } \\
\mu \mathrm{g} / \mathrm{L} \\
(01092)\end{array}$ & $\begin{array}{c}\text { Radon- } \\
\text { 222, } \\
\text { unfiltered, } \\
\text { picoCuries } \\
\text { per liter } \\
\text { (82303) }\end{array}$ & $\begin{array}{c}\text { Uranium, } \\
\text { unfiltered, } \\
\mu \mathrm{g} / \mathrm{L} \\
(28011)\end{array}$ \\
\hline \multicolumn{8}{|c|}{ Sand and gravel wells } \\
\hline HE622 & E 0.1 & 1.96 & 0.71 & 651 & 9 & 450 & 0.221 \\
\hline HE625 & .3 & .31 & $<.08$ & 197 & $<2$ & 530 & .210 \\
\hline HE1144 & E. 2 & .76 & .11 & 171 & E 1 & 440 & .245 \\
\hline HE1433 & .2 & .24 & E.04 & 30.2 & 3 & 420 & .166 \\
\hline M281 & 1.2 & 1.42 & $<.08$ & 963 & 6 & 150 & 1.52 \\
\hline MT407 & .2 & .53 & .23 & 178 & 3 & 270 & .322 \\
\hline MT408 & 4.5 & 1.06 & $<.08$ & 2,640 & 10 & 30 & .364 \\
\hline OE1460 & $<.2$ & 1.01 & E.06 & 369 & E 2 & 480 & .151 \\
\hline OE1462 & .9 & .75 & $<.08$ & 1,510 & 4 & 40 & .579 \\
\hline OE1841 & .5 & .42 & $<.08$ & 782 & 3 & 70 & .314 \\
\hline SA1501 & 1.0 & 2.29 & $<.08$ & 237 & $<2$ & 500 & .236 \\
\hline SN135 & .4 & .89 & .09 & 293 & 4 & 440 & .242 \\
\hline SO9 & 1.0 & .63 & .28 & 549 & 2 & 80 & .810 \\
\hline \multicolumn{8}{|c|}{ Bedrock wells } \\
\hline FU426 & .9 & 1.06 & .40 & 34.2 & 11 & 670 & .076 \\
\hline FU1265 & 4.4 & .56 & $<.08$ & 396 & $<2$ & 660 & .107 \\
\hline G1170 & 2.5 & 2.48 & E.10 & 601 & 16 & 770 & .070 \\
\hline G1351 & 5.9 & 1.21 & $<.08$ & 434 & E 2 & 110 & Е.007 \\
\hline H267 & 3.8 & .17 & $<.08$ & 30.0 & $<2$ & 1,360 & .104 \\
\hline HE1145 & $<.2$ & .38 & .13 & 1,600 & $<2$ & 20 & $<.012$ \\
\hline L475 & E.1 & .34 & $<.08$ & 705 & $<2$ & 20 & $<.012$ \\
\hline MT406 & 2.7 & 1.84 & $<.08$ & 2,090 & 7 & 150 & 1.80 \\
\hline OE1458 & 2.1 & 1.40 & $<.08$ & 614 & 3 & 60 & .130 \\
\hline SA2198 & .8 & 1.91 & E. 05 & 695 & 3 & 50 & .723 \\
\hline SO1374 & 10.4 & 2.23 & E.04 & 5,720 & 5 & 110 & 1.27 \\
\hline SO1384 & .5 & 1.00 & .08 & 31,100 & E 2 & 250 & .393 \\
\hline SO1408 & .8 & .44 & $<.08$ & 437 & E 1 & 1,020 & .471 \\
\hline SO1411 & 6.3 & .84 & $<.08$ & 417 & E 1 & 80 & .201 \\
\hline
\end{tabular}

${ }^{1}$ FU, Fulton County; G, Green County; H, Hamilton County; HE, Herkimer County; L, Lewis County; M, Madison County; MT, Montgomery County; OE, Oneida County; SA, Saratoga County; SN, Schenectady County; SO, Schoharie County. 
Table A7. Concentrations of pesticides and caffeine detected in ground-water samples from the Mohawk River Basin, 2006.

[ $\mu \mathrm{g} / \mathrm{L}$, micrograms per liter; ESA, ethanesulfonic acid; SA, secondary amide; CIAT, 2-chloro-4-isopropylamino-6-amino-striazine; OIET, 2-Hydroxy-4-isopropylamino-6-ethylamino-s-triazine, OA, oxanilic acid; (04040), USGS National Water Information System parameter code; <, less than; E, estimated value; M, presence verified but not quantified; bold values indicate detections]

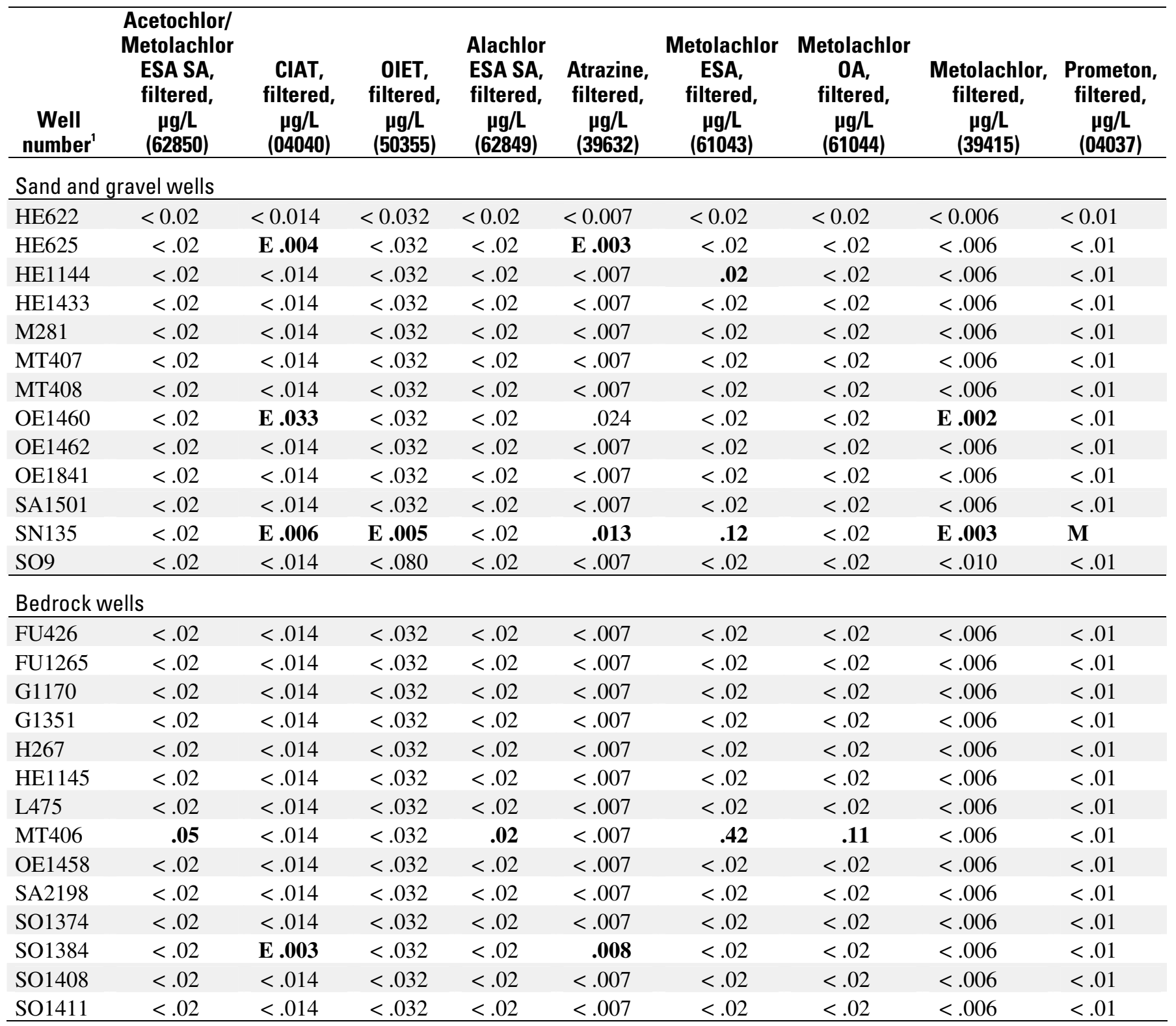

${ }^{1}$ FU, Fulton County; G, Green County; H, Hamilton County; HE, Herkimer County; L, Lewis County; M, Madison County; MT, Montgomery County; OE, Oneida County; SA, Saratoga County; SN, Schenectady County; SO, Schoharie County. 
Table A8. Concentrations of volatile organic compounds and phenolic compounds detected in groundwater samples from the Mohawk River Basin, 2006.

[ $\mu \mathrm{g} / \mathrm{L}$, micrograms per liter; (32730), USGS National Water Information System parameter code; <, less than; bold values indicate detections]

\begin{tabular}{|c|c|c|c|c|c|c|c|}
\hline $\begin{array}{c}\text { Well } \\
\text { number }\end{array}$ & $\begin{array}{c}\text { Total } \\
\text { Phenolic } \\
\text { Compounds, } \\
\text { unfiltered, } \\
\mu \mathrm{g} / \mathrm{L} \\
(\mathbf{3 2 7 3 0}) \\
\end{array}$ & $\begin{array}{c}\text { Bromo- } \\
\text { dichloro- } \\
\text { methane, } \\
\text { unfiltered, } \\
\mu \mathrm{g} / \mathrm{L} \\
(\mathbf{3 2 1 0 1 )} \\
\end{array}$ & $\begin{array}{c}\text { Dibromo- } \\
\text { chloro- } \\
\text { methane, } \\
\text { unfiltered, } \\
\mu \mathrm{g} / \mathrm{L} \\
(\mathbf{3 2 1 0 5}) \\
\end{array}$ & $\begin{array}{c}\text { Tetrachloro- } \\
\text { ethene, } \\
\text { unfiltered, } \\
\mu \mathrm{g} / \mathrm{L} \\
(34475) \\
\end{array}$ & $\begin{array}{c}\text { Toluene, } \\
\text { unfiltered, } \\
\mu \mathrm{g} / \mathrm{L} \\
(\mathbf{3 4 0 1 0}) \\
\end{array}$ & $\begin{array}{c}\text { Tribromo- } \\
\text { methane, } \\
\text { unfiltered, } \\
\mu \mathrm{g} / \mathrm{L} \\
(32104)\end{array}$ & $\begin{array}{c}\text { Trichloro- } \\
\text { methane, } \\
\text { unfiltered, } \\
\mu \mathrm{g} / \mathrm{L} \\
(32106)\end{array}$ \\
\hline \multicolumn{8}{|c|}{ Sand and gravel wells } \\
\hline HE622 & $<4$ & 0.3 & 0.7 & $<0.1$ & $<.1$ & 0.8 & 0.2 \\
\hline HE625 & $<4$ & $<.1$ & $<.2$ & $<.1$ & $<.1$ & $<.2$ & $<.1$ \\
\hline HE1144 & $<4$ & $<.1$ & $<.2$ & $<.1$ & $<.1$ & $<.2$ & $<.1$ \\
\hline HE1433 & $<4$ & $<.1$ & $<.2$ & $<.1$ & $<.1$ & $<.2$ & $<.1$ \\
\hline M281 & 8 & $<.1$ & $<.2$ & $<.1$ & $<.1$ & $<.2$ & $<.1$ \\
\hline MT407 & 4 & $<.1$ & $<.2$ & $<.1$ & $<.1$ & $<.2$ & .1 \\
\hline MT408 & $<4$ & $<.1$ & $<.2$ & $<.1$ & $<.1$ & $<.2$ & $<.1$ \\
\hline OE1460 & $<4$ & .1 & .3 & .4 & .2 & .5 & .1 \\
\hline OE1462 & $<4$ & $<.1$ & $<.2$ & $<.1$ & $<.1$ & $<.2$ & $<.1$ \\
\hline OE1841 & $<4$ & $<.1$ & $<.2$ & $<.1$ & $<.1$ & $<.2$ & $<.1$ \\
\hline SA1501 & $<4$ & $<.1$ & $<.2$ & $<.1$ & $<.1$ & $<.2$ & $<.1$ \\
\hline SN135 & $<4$ & $<.1$ & $<.2$ & $<.1$ & $<.1$ & $<.2$ & $<.1$ \\
\hline SO9 & $<4$ & $<.1$ & $<.2$ & $<.1$ & $<.1$ & $<.2$ & $<.1$ \\
\hline \multicolumn{8}{|c|}{ Bedrock wells } \\
\hline FU426 & $<4$ & $<.1$ & $<.2$ & $<.1$ & $<.1$ & $<.2$ & $<.1$ \\
\hline FU1265 & $<4$ & $<.1$ & $<.2$ & $<.1$ & .2 & $<.2$ & $<.1$ \\
\hline G1170 & $<4$ & $<.1$ & $<.2$ & $<.1$ & $<.1$ & $<.2$ & $<.1$ \\
\hline G1351 & $<4$ & $<.1$ & $<.2$ & $<.1$ & $<.1$ & $<.2$ & $<.1$ \\
\hline H267 & $<4$ & $<.1$ & $<.2$ & $<.1$ & $<.1$ & $<.2$ & $<.1$ \\
\hline HE1145 & $<4$ & $<.1$ & $<.2$ & $<.1$ & $<.1$ & $<.2$ & $<.1$ \\
\hline L475 & $<4$ & $<.1$ & $<.2$ & $<.1$ & $<.1$ & $<.2$ & $<.1$ \\
\hline MT406 & $<4$ & $<.1$ & $<.2$ & $<.1$ & $<.1$ & $<.2$ & $<.1$ \\
\hline OE1458 & $<4$ & $<.1$ & $<.2$ & $<.1$ & $<.1$ & $<.2$ & $<.1$ \\
\hline SA2198 & $<4$ & $<.1$ & $<.2$ & $<.1$ & $<.1$ & $<.2$ & $<.1$ \\
\hline SO1374 & $<4$ & $<.1$ & $<.2$ & $<.1$ & $<.1$ & $<.2$ & $<.1$ \\
\hline SO1384 & $<4$ & $<.1$ & $<.2$ & $<.1$ & $<.1$ & $<.2$ & $<.1$ \\
\hline SO1408 & 13 & $<.1$ & $<.2$ & $<.1$ & $<.1$ & $<.2$ & $<.1$ \\
\hline SO1411 & $<4$ & $<.1$ & $<.2$ & $<.1$ & $<.1$ & $<.2$ & $<.1$ \\
\hline
\end{tabular}

${ }^{1}$ FU, Fulton County; G, Green County; H, Hamilton County; HE, Herkimer County; L, Lewis County; M, Madison County; MT, Montgomery County; OE, Oneida County; SA, Saratoga County; SN, Schenectady County; SO, Schoharie County. 
Table A9. Bacteria in ground-water samples from the Mohawk River Basin, 2006.

[CFU, colony-forming unit; mL, milliliter; (78943), USGS National Water Information System parameter code; <, less than; E, estimated value; TNTC, too numerous to count; bold values exceed one or more drinking water standards]

\begin{tabular}{|c|c|c|c|c|}
\hline $\begin{array}{c}\text { Well } \\
\text { number' }\end{array}$ & $\begin{array}{l}\text { Heterotrophic } \\
\text { plate count, } \\
\text { unfiltered, } \\
\text { CFU/mL } \\
\text { (78943) }\end{array}$ & $\begin{array}{c}\text { Escherichia } \\
\text { coli, } \\
\text { unfiltered, } \\
\text { Presence } \\
\text { /Absence } \\
\text { (50278) }\end{array}$ & $\begin{array}{c}\text { Fecal } \\
\text { coliform, } \\
\text { unfiltered, } \\
\text { CFU/100mL } \\
(31625)\end{array}$ & $\begin{array}{c}\text { Total coliform, } \\
\text { unfiltered, } \\
\text { CFU/100mL } \\
(31501)\end{array}$ \\
\hline \multicolumn{5}{|c|}{ Sand and gravel wells } \\
\hline HE622 & $<1$ & Negative & $\mathrm{E}<5$ & $<1$ \\
\hline HE625 & 2 & Negative & $\mathrm{E}<5$ & 3 \\
\hline HE1144 & 140 & Negative & $\mathrm{E}<5$ & $<1$ \\
\hline HE1433 & 33 & Negative & $\mathrm{E}<5$ & $<1$ \\
\hline M281 & $<1$ & Negative & $\mathrm{E}<5$ & $<1$ \\
\hline MT407 & $<1$ & Negative & $\mathrm{E}<5$ & Positive* \\
\hline MT408 & 35 & Negative & $\mathrm{E}<5$ & $<1$ \\
\hline OE1460 & 13 & Negative & $\mathrm{E}<5$ & $<1$ \\
\hline OE1462 & 1 & Negative & $\mathrm{E}<5$ & $<1$ \\
\hline OE1841 & 23 & Negative & $\mathrm{E}<5$ & 100 \\
\hline SA1501 & $<1$ & Negative & $\mathrm{E}<5$ & $<1$ \\
\hline SN135 & 250 & Negative & $\mathrm{E}<5$ & $<1$ \\
\hline SO9 & $<1$ & Negative & $\mathrm{E}<5$ & $<1$ \\
\hline \multicolumn{5}{|c|}{ Bedrock wells } \\
\hline FU426 & 4 & Negative & $\mathrm{E}<5$ & $<1$ \\
\hline FU1265 & $<1$ & Negative & $\mathrm{E}<5$ & $<1$ \\
\hline G1170 & 15 & Negative & $\mathrm{E}<5$ & $<1$ \\
\hline G1351 & 46 & Negative & $\mathrm{E}<5$ & $<1$ \\
\hline H267 & 3 & Negative & $\mathrm{E}<5$ & $<1$ \\
\hline HE1145 & 77 & Negative & $\mathrm{E}<5$ & $<1$ \\
\hline L475 & 70 & Negative & $\mathrm{E}<5$ & TNTC \\
\hline MT406 & 2 & Negative & $\mathrm{E}<5$ & $<1$ \\
\hline OE1458 & 2 & Negative & $\mathrm{E}<5$ & $<1$ \\
\hline SA2198 & 110 & Negative & $<2 *$ & $<1$ \\
\hline SO1374 & 17 & Negative & $\mathrm{E}<5$ & 1 \\
\hline SO1384 & $<1$ & Negative & $\mathrm{E}<5$ & 25 \\
\hline SO1408 & $<1$ & Negative & $\mathrm{E}<5$ & $<1$ \\
\hline SO1411 & E 940 & Negative & $E<5$ & $<1$ \\
\hline
\end{tabular}

${ }^{1}$ FU, Fulton County; G, Green County; H, Hamilton County; HE, Herkimer County; L, Lewis County; M, Madison County; MT, Montgomery County; OE, Oneida County; SA, Saratoga County; SN, Schenectady County; SO, Schoharie County.

* Processed with defined-substrate technology instead of membrane filtration. 